\title{
Sedimentary facies analysis of the fluvial environment in the Siwalik Group of eastern Nepal: deciphering its relation to contemporary Himalayan tectonics, climate and sea-level change
}

\author{
Lalit Kumar Rai ${ }^{1 *}$ and Kohki Yoshida ${ }^{2}$
}

\begin{abstract}
The Siwalik Group, ranging from the Early Miocene to Pleistocene, is believed to be deposited in the fluvial environment and controlled by contemporary Himalayan tectonics and climate. In this study, we established the fluvial environment and its controlling factors responsible for the deposition of the Siwalik succession along the Muksar Khola section in the eastern Nepal Himalaya. Five sedimentary facies associations are identified; these are interpreted as the deposits of flood plain-dominated fine-grained meandering river (FA1), flood-dominated overbank environment (FA2), sandy meandering river (FA3), anastomosing river (FA4), and debris flow-dominated gravelly braided river (FA5). These changes in the fluvial system occurred around 10.5 Ma, 10.0 Ma, 5.9 Ma and 3.5 $\mathrm{Ma}$, defined by existing magnetostratigraphy constraints, due to the effects of hinterland tectonics, climate and sealevel change and continuous drifting of the foreland basin towards the hinterland concerning depositional age. The thick succession of an intraformational conglomerate reveals intensification of the monsoon started around $10.5 \mathrm{Ma}$ in the eastern Nepal Himalaya. The present study also shows asynchronous exhumation of the Himalaya from east to west brought a significant difference in the fluvial environment of the Neogene foreland basin.
\end{abstract}

Keywords: Miocene, Siwaliks, Facies, Fluvial, Sea-level change, Eastern Nepal Himalaya

\section{Introduction}

Himalaya was gradually uplifted due to the collision of the Indian sub-continent with the Eurasian plate at ca. $50 \mathrm{Ma}$ (Le Fort 1975; Burbank 1992). Various tectonic activities have been recorded in the Himalaya after this collision (Burchfiel et al. 1992). This gradual change in the paleogeography influenced the atmospheric circulation (Raymo and Ruddiman 1992) triggering the Asian monsoon (Kutzbach et al. 1989; Clift et al. 2008; Boos and Kuang 2010; Armstrong and Allen 2011), which in

\footnotetext{
* Correspondence: Ialitrai83@gmail.com

1 Department of Science and Technology, Graduate School of Medicine,

Science and Technology, Shinshu University, Matsumoto, Japan

Full list of author information is available at the end of the article
}

turn controlled the weathering and erosional process that was responsible for the deposition of sediments in the foreland basin (Parkash et al. 1980; Tokuoka et al. 1990; Willis 1993b; Zaleha 1997). The Siwalik Group is made up of this molasse deposits (Corvinus 1993) derived from the Himalaya and deposited by the fluvial system (Tandon 1976; Parkash et al. 1980; Tokuoka et al. 1990; Hisatomi and Tanaka 1994; Willis 1993b) in the paleo-Gangetic basin during the Early Miocene to Pleistocene time (Appel and Rosler 1994; Gautam and Appel 1994; Rosler et al. 1997; Gautam and Fujiwara 2000; Ojha et al. 2009). Presently, it is exposed as the southernmost hill range bounded by the Main Boundary 
Thrust (MBT) to the north and the Main Frontal Thrust in the south (Gansser 1964).

In the previous studies of the Siwalik Group along various sections of the Himalaya, the appearance of the Middle Siwalik sub-group represented by the 'salt and pepper' sandstone, supplied from the Higher Himalaya that existed as a positive relief at that time due to tectonic upliftment (Khan et al. 1997; Kumar et al. 1999, 2003a, 2003b; Kumar and Tandon 1985; Zaleha 1997) is observed to be followed by the change in the river systems from meandering to the sandy braided river system (Hisatomi and Tanaka 1994; Zaleha 1997; Ulak and Nakayama 2001; Ulak 2009; Sigdel and Sakai 2016). These two river systems are observed as a dominating fluvial system during the deposition of the Siwaliks, although anastomosing river system has also been recorded in few sections (Huyghe et al. 2005; Nakayama and Ulak 1999). This change in the fluvial system is considered to be controlled by both autocyclic as well as allocyclic processes like hinterland tectonics, climate, and size of drainage basins (Willis 1993a; Zaleha 1997; Nakayama and Ulak 1999; Huyghe et al. 2005).

Meanwhile, various researchers suggested that the exhumation history of the Himalaya, as well as the climate, was not synchronous laterally; it was observed early in the western part compared with the eastern part (Quade et al. 1995; Robinson et al. 2001; Yin 2006; Ojha et al. 2009; Vogeli et al. 2017). Therefore, if the tectonics and climate are the factors controlling the change in the river system of the Neogene foreland basin, then these differences in the Himalaya from west to east should also have brought a significant difference in the fluvial environment and its timing laterally. Moreover, fluvial behaviour is governed not only by the interplay between tectonics and climate but also by sea-level change (Burbank 1992; Goodbred Jr and Kuehl 2000a; Goodbred Jr and Kuehl 2000b). The Siwalik Group in the eastern Himalaya sections like Darjeeling-Sikkim, Bhutan and the Arunachal Pradesh report the evidence of sediment deposited in deltaic and open marine depositional settings (Coutand et al. 2016; Taral et al. 2018, 2019). The present study area lies in the eastern part of the Nepal Himalaya near the DarjeelingSikkim section. Therefore, the contemporary exhumation history of the hinterland, climate as well as sea-level change should influence the fluvial environment, though the effect of the sea-level change was not mentioned in the previous studies of the fluvial environment of the Siwalik Group in eastern Nepal (Ulak 2009).

In this study, we focused on establishing the fluvial environment of the Siwalik Group along the Muksar Khola section in the eastern Nepal Himalaya based on facies analysis to understand its evolution and its controlling factors. Interpretation will be carried out using the depositional age determined by Ojha et al. (2009).

\section{Geological outline}

The present study area lies in the eastern part of the Nepal Himalaya (Fig. 1A). In this area, the Siwalik Group is divided into three belts by the Main Dun Thrust and the Kamala-Tawa Thrust (Shrestha and Sharma 1996). The present study deals with the Siwalik Group in the southern belt, bounded by the Main Dun Thrust in the north and the Main Frontal Thrust in the south. Lithostratigraphy of the Siwalik Group in the southern belt along the Muksar Khola section is established by Rai and Yoshida (2020). The $>4 \mathrm{~km}$ thick Siwalik Group is divided into the Lower Siwalik sub-group, the lower member of the Middle Siwalik sub-group, the upper member of the Middle Siwalik sub-group and the Upper Siwalik sub-group (Fig. 1B). The Lower Siwalik subgroup comprises grey, fine-grained indurated sandstone with dark greenish grey and purple mottled mudstone. About 80 to $90 \mathrm{~m}$ thick successions of intraformational conglomerate (composed of mudstone clast with medium- to very coarse-grained sandstone matrix) are present within the middle part of the exposed section of the Lower Siwalik sub-group. The lower member of the Middle Siwalik sub-group is characterized by "salt and pepper" appearance medium-grained sandstone, with dark greenish grey mudstone to siltstone. The upper member of the Middle Siwalik sub-group consists of light grey, medium- to coarse-grained sandstone with some pebbly layers and grey to dark grey mudstone to siltstone. Sandstones are less indurated with a decrease in the proportion of biotite grains, and the mudstone shows increased proportion compared with the lower member of the Middle Siwalik sub-group. The Upper Siwalik sub-group is composed of a poorly sorted, pebble to cobble conglomerate. These conglomerate beds are frequently interbedded with thick massive, coarsegrained sandstone and dull-yellow to yellowish-grey mudstone to siltstone beds. The magnetostratigraphic study by Ojha et al. (2009) indicates that the $\sim 2500 \mathrm{~m}$ thick Middle Siwalik sub-group along the Muksar Khola was deposited between 10.0 and $3.5 \mathrm{Ma}$.

Previous studies of the eastern Nepal Himalaya shows a change in the hinterland exhumation rate; a fast exhumation similar to the central and western Nepal was observed during the deposition of the lower member of the Middle Siwalik sub-group but was absent during the deposition of the upper member of the Middle Siwalik sub-group (Chirouze et al. 2012). This fast exhumation was observed after 11.0 Ma as rapid uplift of the Higher Himalayan Crystalline occurred due to the activation of an out-of-sequence thrust known as the Sun Koshi Thrust (Rai et al. 2021). Similarly, after $\sim 5.5 \mathrm{Ma}$, rapid subsidence of the foreland basin was observed as a result of the thrust loading of the MBT (Ojha et al. 2009; Rai et al. 2021). The climate of the eastern Nepal Himalaya 


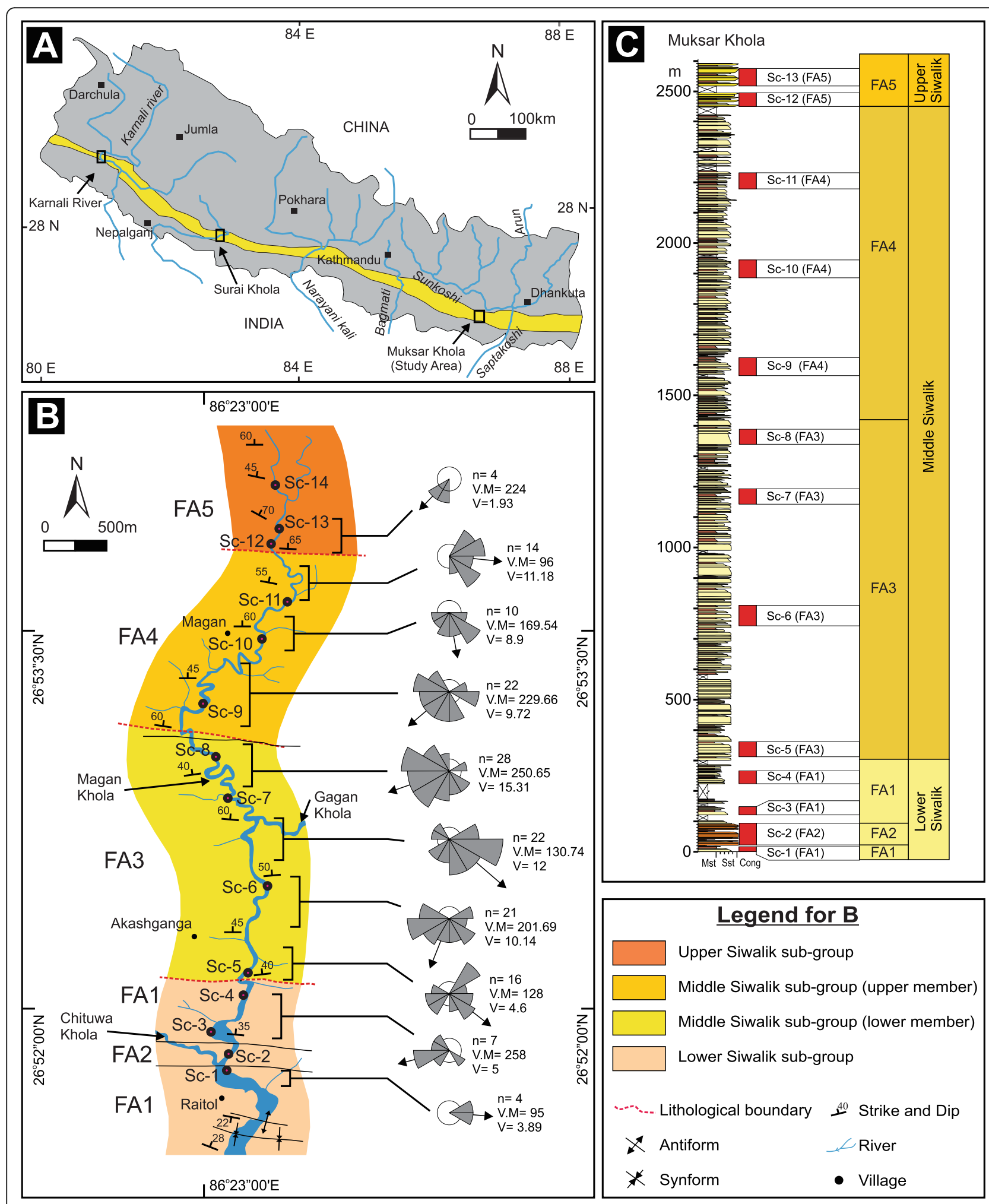

Fig. 1 A Map of Nepal (in grey) showing the Siwaliks range (in yellow) and the location of the present study area along with the Surai Khola section studied by Nakayama and Ulak (1999) and Karnali River section studied by Huyghe et al. (2005) and Sigdel and Sakai (2016); B geological map of the Siwaliks along the Muksar Khola section (modified after Rai and Yoshida 2020) showing the location of representative sedimentological log of the facies association and paleocurrent analysis; $\mathbf{C}$ sedimentological log of the Muksar Khola section (modified after Rai and Yoshida 2020) showing the location of sedimentological log of representative facies association (Sc-14 of FA5 lies beyond the sedimentological log) 
shows a more or less similar trend to the Central Nepal Himalaya (Quade et al. 1995), but lacks the exact time frame of vegetation change from $\mathrm{C} 3$ to $\mathrm{C} 4$ plant. Comparing the stratigraphic thickness of Quade et al. (1995) with the magnetostratigraphy of Ojha et al. (2009), this change in the vegetation probably occurred around 6 to $7 \mathrm{Ma}$. This change in the vegetation suggests a greater seasonality reflected by a stronger monsoon (Quade et al. 1989, 1995).

\section{Methods}

In this study, field data were acquired based on the topographic map of the 1:25,000 scale. Lithofacies were identified based on the grain size and texture of the beds and associated sedimentary structures. Architectural elements were classified based on the nature of the internal and external geometry of the beds and their bounding surfaces. Mainly, foresets of the cross-stratifications were measured for the paleocurrent analysis. The paleoflow direction was estimated using standard methods (Tucker 2003). Based on these lithofacies, architectural elements and paleocurrent directions, facies associations were classified following the code of Miall (1977, 1985, 2000, 2006). Route map and detail sedimentological logs were made to evaluate the precise boundary of the facies associations. The paleomagnetic data by Ojha et al. (2009) was used to determine the specific age for each facies association. Based on this facies association, river systems were interpreted.

\section{Results}

\subsection{Facies associations}

Based on sandstone-mudstone ratio, grain size, assemblages of sedimentary structures and the nature of the beds, 12 sedimentary lithofacies and five facies associations have been recognized. The lithofacies are summarized in Table 1, and the representative photographs of each lithofacies are shown in Fig. 2. The recognized facies associations along with its associate lithofacies and architectural elements are summarized in Table 2. Representative sedimentological logs of each facies associations are shown in Fig. 3 and their locations in Fig. 1B \& C.

\subsubsection{Facies association 1 (FA1)}

4.1.1.1 Description This facies association is characterized by a predominance of thickly bedded mudstone interbedded with very fine- to medium-grained sandstone. Normally, fining-upward successions from fine-grained sandstone to mudstone are found in this facies association. Mudstones are olive-grey to dark-grey and reddish-brown with thickness ranging from 0.4 to $2.0 \mathrm{~m}$. Mudstone is dominated by facies Fm (mostly bioturbated), with abundant facies $\mathrm{Fl}$ and facies $\mathrm{P}$ (Fig. 2A). Facies $\mathrm{C}$ is also observed occasionally (Fig. 2B).
Sandstone beds normally range between 0.15 and 1.5 $\mathrm{m}$ in thickness, though there are few beds with a thickness of more than $4 \mathrm{~m}$ (Fig. 3, Sc-1 \& 4). Thick to very thick beds $(>70 \mathrm{~cm})$ of fine- to medium-grained sandstone show facies $\mathrm{Sp}$ with an erosive basal surface, whereas in the thick beds $(30-60 \mathrm{~cm})$, facies $\mathrm{Sr}$ and $\mathrm{Sh}$ dominates. Lateral accretionary structures are mainly observed in these beds. Medium- to thickly bedded finegrained sandstone is massive with occasional occurrence of facies Sr. Very fine- to fine-grained sandstones display both fining- and coarsening-upward succession with facies Fm (Fig. 2C) and often possess concretions. The basal surface is comparatively flat and usually occurs at an interval within very thick beds of mudstone (Fig. 3, Sc-4). Thin- to medium-bedded very fine-grained sandstones are bioturbated if not show facies Fl (Fig. 2D). Calcareous nodules are often observed on 15-25 cm thick upper portion of the fine-grained sandstone and mudstone beds. Sandpipes oriented almost perpendicular to bed with diameter ca. $3 \mathrm{~cm}$ (Fig. 2C), roots and rootlets are observed in mudstone and very fine-grained sandstone. Though the paleocurrent data are limited in this facies association but still show a dispersive flow pattern (Fig. 1B). Facies association FA1 is preserved in the Lower Siwalik sub-group.

4.1.1.2 Interpretation Thick to very thick beds of fineto medium-grained sandstone showing planar crossstratification and ripple cross lamination with erosive basal surface represents channel deposits (Miall 2006). Medium to thick massive, fine-grained sandstone with an occasional ripple cross-lamination represents sheet flow (Miall 2006). Medium-bedded very fine- to finegrained sandstone with either fining- or coarseningupward succession with concretions, occurring at an interval within flood plain deposits suggests crevasse deposits (Nakayama and Ulak 1999; Miall 2006). Thin to medium beds of very fine-grained sandstones showing parallel to ripple cross-laminations are levee deposits (Singh 1972). The flat basal surface of these finegrained sandstones and its occurrence at an interval within very thick beds of mudstone suggests overbank deposits (Miall 2006). Laminated and peaty mudstone represents the waning stage of river flood and swamp deposits indicating the overbank deposits (Miall 2000, 2006). Variegated and bioturbated mudstone with sandpipes, rootlets and the presence of calcareous nodules indicate long term exposure of the flood plain (Nakayama and Ulak 1999). Sandstone with lateral accretionary structures along with dispersive paleoflow pattern and frequent crevasse splay suggests a river with high sinuosity. Therefore, FA1 is interpreted as the deposits of a flood plain-dominated fine-grained meandering river system. 
Table 1 Description and interpretation of the depositional facies of the Siwalik Group along the Muksar Khola section

\begin{tabular}{|c|c|c|c|c|c|}
\hline $\begin{array}{l}\text { Facies } \\
\text { Code }\end{array}$ & Symbol & $\begin{array}{c}\text { Facies } \\
\text { Characteristics }\end{array}$ & $\begin{array}{l}\text { Sedimentary } \\
\text { Structures }\end{array}$ & Interpretation & Remarks \\
\hline Gmm & 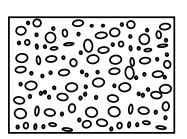 & $\begin{array}{l}\text { Matrix supported, poorly sorted } \\
\text { massive gravel } \\
\text { Thickness } 2 \text { to } 8 \mathrm{~m}\end{array}$ & $\begin{array}{l}\text { Structureless or } \\
\text { weak grading }\end{array}$ & $\begin{array}{l}\text { Plastic debris flow } \\
\text { (high strength, viscous), } \\
\text { longitudinal bars, channel lag } \\
\text { deposits (Miall, 1977; 2000; 2006) }\end{array}$ & Fig: $2-\mathrm{L}$ \\
\hline Gn & 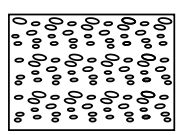 & $\begin{array}{l}\text { Matrix supported gravel } \\
\text { Thickness } 2 \text { to } 8 \mathrm{~m}\end{array}$ & $\begin{array}{l}\text { Inverse grading } \\
\text { Grading clast } \\
\text { and/or matrix }\end{array}$ & $\begin{array}{l}\text { Pseudoplastic debris flow } \\
\text { (low strength, viscous), } \\
\text { longitudinal bars, channel lag } \\
\text { deposits (Miall, 1977;2000; 2006) }\end{array}$ & Fig: $2-\mathrm{K}$ \\
\hline & 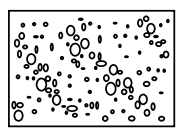 & $\begin{array}{l}\text { Pebble sized clast stratified in } \\
\text { matrix of medium- to } \\
\text { coarse-grained sandstones } \\
\text { Thickness upto } 2 \mathrm{~m}\end{array}$ & Planar cross beds & $\begin{array}{l}\text { Transverse bedforms, linguoid } \\
\text { bars or deltaic growths from } \\
\text { older bar remnants } \\
\text { (Miall, 1977; 2000; 2006) }\end{array}$ & Fig: 2-J \\
\hline & & $\begin{array}{l}\text { Fine- to medium-grained } \\
\text { sandstones, occasionally } \\
\text { concreted } \\
\text { Thickness upto } 0.4 \mathrm{~m}\end{array}$ & $\begin{array}{l}\text { Horizontal lamination } \\
\text { with parting or } \\
\text { streaming lineation }\end{array}$ & $\begin{array}{l}\text { Planar bed flow (intermediate to } \\
\text { upper flow regime or lower flow } \\
\text { regime) } \\
\text { (Miall, } 1977 ; 2000 ; 2006 \text { ) }\end{array}$ & Fig: $2-I$ \\
\hline & $\underset{\psi}{\psi}$ & $\begin{array}{l}\text { Medium- to coarse-grained } \\
\text { sandstones, } \\
\text { occasionally pebbly } \\
\text { Thickness upto } 2 \mathrm{~m}\end{array}$ & $\begin{array}{l}\text { Solitary or grouped } \\
\text { trough cross beds }\end{array}$ & $\begin{array}{l}\text { Migration of linguoid 3D dunes } \\
\text { (lower flow regime) } \\
\text { (Miall, 1977; 2000; 2006) }\end{array}$ & Fig: $2-\mathrm{H}$ \\
\hline & & $\begin{array}{l}\text { Medium- to coarse-grained } \\
\text { sandstones } \\
\text { Thickness upto } 1.5 \mathrm{~m}\end{array}$ & $\begin{array}{l}\text { Massive or } \\
\text { faint lamination }\end{array}$ & $\begin{array}{l}\text { Sediment gravity flow deposits, } \\
\text { resulting from high concentration of } \\
\text { sediment / water mixture (Martin and } \\
\text { Turner, 1998; Miall, 2000; 2006) }\end{array}$ & Fig: $2-G$ \\
\hline & & $\begin{array}{l}\text { Fine- to coarse-grained } \\
\text { sandstones, mudclast are } \\
\text { occasionally present } \\
\text { Thickness upto } 1 \mathrm{~m}\end{array}$ & $\begin{array}{l}\text { Solitary or grouped } \\
\text { planar cross beds }\end{array}$ & $\begin{array}{l}\text { Migration transverse and linguoid } \\
\text { 2D dunes (lower flow regime) } \\
\text { (Miall, 1977; 2000; 2006) }\end{array}$ & Fig: 2-F \\
\hline & & $\begin{array}{l}\text { Fine- to medium-grained } \\
\text { sandstones, occasionally } \\
\text { concreted } \\
\text { Thickness upto } 0.4 \mathrm{~m}\end{array}$ & $\begin{array}{l}\text { Ripple cross } \\
\text { lamination }\end{array}$ & $\begin{array}{l}\text { Ripples } \\
\text { (lower flow regime) } \\
\text { (Miall, 1977; 2000; 2006) }\end{array}$ & Fig: 2-E \\
\hline & & $\begin{array}{l}\text { Inter-lamination of mud, silt and } \\
\text { very fine-grained sand with } \\
\text { occasional very small ripples } \\
\text { Thickness upto } 1 \mathrm{~m}\end{array}$ & $\begin{array}{l}\text { Fine parallel } \\
\text { lamination }\end{array}$ & $\begin{array}{l}\text { Overbank or waning flood } \\
\text { deposits (Miall, 1977; 2000; 2006) }\end{array}$ & Fig: 2-D \\
\hline $\mathrm{m}$ & & $\begin{array}{l}\text { Mudstones to very } \\
\text { fine-grained sandstones } \\
\text { Thickness upto } 0.3 \mathrm{~m}\end{array}$ & $\begin{array}{l}\text { Massive or } \\
\text { bioturbated }\end{array}$ & $\begin{array}{l}\text { Overbank, abandoned channel, } \\
\text { or drape deposits } \\
\text { (Miall, 1977; 2000; 2006) }\end{array}$ & Fig: $2-C$ \\
\hline & & $\begin{array}{l}\text { Peaty mudstones } \\
\text { Thickness upto } 0.15 \mathrm{~m}\end{array}$ & Plant, mud films & $\begin{array}{l}\text { Vegetated swamp deposits } \\
\text { (Miall, 2000; 2006) }\end{array}$ & Fig: 2-B \\
\hline & & $\begin{array}{l}\text { Variegated with nodules } \\
\text { and concretions } \\
\text { Thickness upto } 2 \mathrm{~m}\end{array}$ & $\begin{array}{l}\text { Pedogenic } \\
\text { features }\end{array}$ & $\begin{array}{l}\text { Soil with chemical precipitation } \\
\text { (Miall, 2000; 2006) }\end{array}$ & Fig: 2-A \\
\hline
\end{tabular}

\subsubsection{Facies association 2 (FA2)}

4.1.2.1 Description This facies association is mainly characterized by the thick- to very thickly bedded ( 0.4 to $>4.0 \mathrm{~m}$ ), poorly sorted, clast-supported intraformational conglomerate (Fig. 4A) with few beds of coarse-grained sandstone and mudstone. The intraformational conglomerate is composed up of siltstone clast and medium- to very coarse-grained sandstone matrix and shows facies $\mathrm{Gmm}$. These siltstone clasts are greenishgrey in colour and angular to subangular in shape (some clasts shows ductile deformation) with an average 

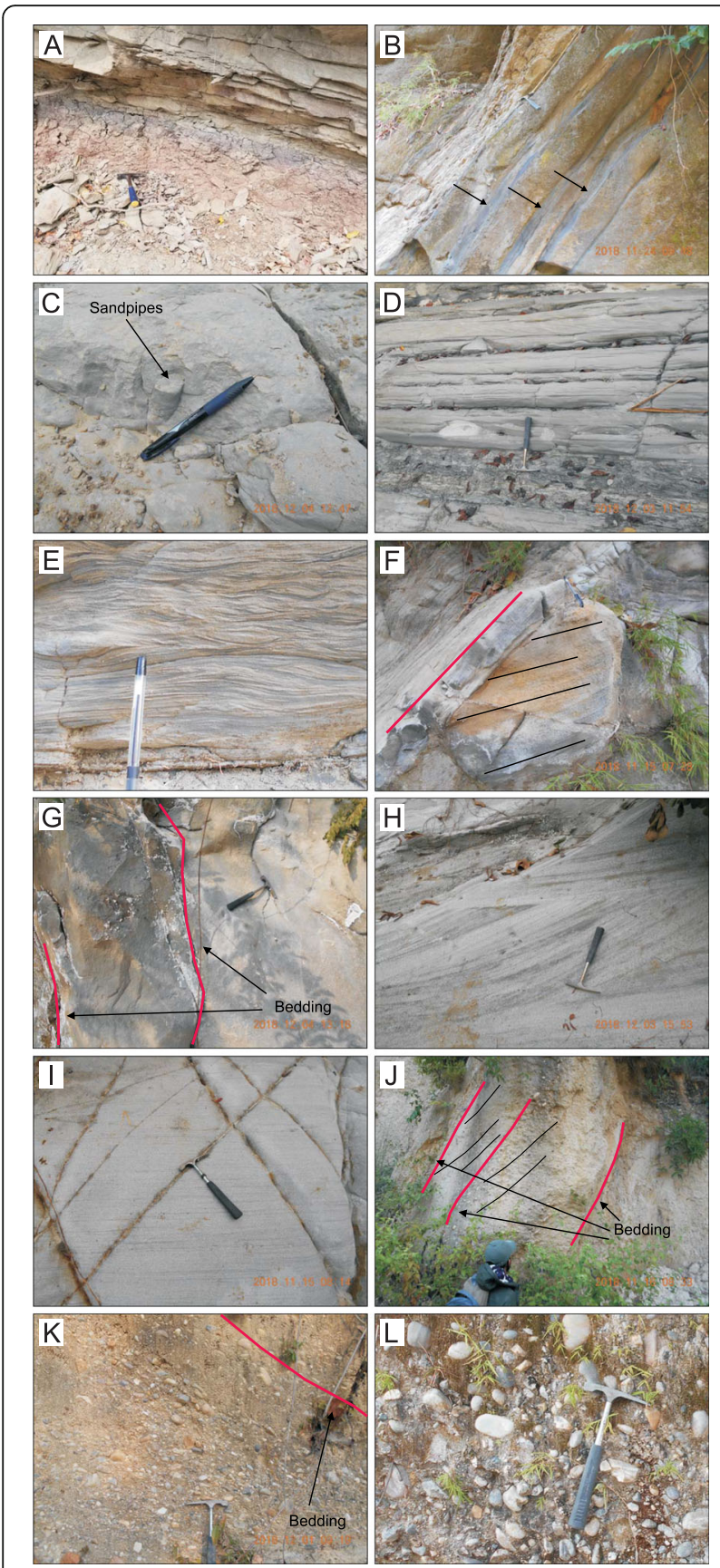

Fig. 2 Representative outcrop photographs of the 12 lithofacies. A Reddish-brown mudstone (facies P) from FA1, B peaty mudstone (facies C) from FA1, C massive mudstone (facies Fm) with sandpipes from FA1, D mudstone to very fine-grained sandstone with parallel lamination (facies FI) from FA1, E fine-grained sandstone with ripple cross-lamination (facies Sr) from FA2, F medium-grained sandstone with planer cross-stratification (facies Sp) from FA3, G massive (facies $\mathrm{Sm}$ ) sandstone from FA3, $\mathbf{H}$ sandstone with trough cross-stratification (facies St) from FA4, I sandstone with horizontal lamination (facies Sh) from FA4, J conglomerate showing weak planer cross-stratification (facies Gp) from FA5, K matrix-supported gravelly conglomerate with inverse grading (facies Gmg) from FA5, L matrix-supported poorly sorted pebble to cobble size massive conglomerate (facies $\mathrm{Gmm}$ ) from FA5 diameter of 1-4 $\mathrm{cm}$ (some clasts show elongation up to $10 \mathrm{~cm}$ ). The average ratio of clast and matrix is about $70 \%$ and $30 \%$ respectively. This intraformational conglomerate shows a non-erosional basal surface. Coarsegrained sandstone beds with facies Sm are observed at the lower part of this facies association within the beds of intraformational conglomerate. These massive sandstones have a flat basal surface with thickness ranging from 0.1 to $0.8 \mathrm{~m}$. In the upper part of this facies association, sandstone facies disappears with occasional occurrence of 0.4 to $0.5 \mathrm{~m}$ thick mudstones with facies Fl (Fig. 3, Sc-2). Facies Fm is also occasionally observed in mudstone but very rare. At the top of this facies association, thin to medium beds of fine-grained sandstone (overall thickness of around $10 \mathrm{~m}$ ) with facies Sr (Fig. 2E) interbedded with facies $\mathrm{Fl}$ is observed (Figs. 3, Sc-2 \& 4B). The FA2 facies association is preserved in the Lower Siwalik sub-group within facies association FA1 with a thickness of about 80 to $90 \mathrm{~m}$.

4.1.2.2 Interpretation An intraformational conglomerate suggests bank failure due to the rapid lowering of water levels during the waning stage of a flood (Gohain and Parkash 1990; Singh et al. 1993; Plink-Bjorklund 2015). Singh et al. (1993) suggested during the falling stage of the flood, banks are undercut by the current initiating the development of shear cracks. Further parts of the bank slump and melts away, in the case of the cohesive muddy bank, they break into large blocks. These large blocks change to angular and then to rounded clasts with a decrease in size as they roll along the channel floor for some distance. Such collapse of fluvial banks initiates sediment-laden currents movement across and along the fluvial channel (Martin and Turner 1998). But an angular to subangular shape of mud clast indicates immature sediments that were not transported for a longer distance (Reineck and Singh 1980) (i.e., the source of these clasts were proximal to the place of deposition). If this conglomerate was deposited by the main channel undercutting the adjacent overbank deposits, there would be a possibility of much longer transportation and soon disintegration of these clasts. Moreover, the structureless beds of intraformational conglomerate with planer basal surface also suggest this was not deposited by channel, rather by some debris flow (Miall 2006). Therefore, we consider that this was not deposited by the main channel collapsing adjacent flood plain during the waning stage of the flood, but in the overbank setting, more distal to the main channel due to the collapse of the distal alluvial terraces. This collapse of the alluvial terraces was probably triggered by the flood which covered the adjacent flood plain and undercut the alluvial terraces similar to the bank cut during the waning stage of a flood. The increase in the 
Table 2 Facies associations of the Siwalik Group in the Muksar Khola section

\begin{tabular}{|c|c|c|c|c|c|}
\hline $\begin{array}{l}\text { Facies } \\
\text { association }\end{array}$ & $\begin{array}{l}\text { Dominant lithofacies } \\
\text { type }\end{array}$ & $\begin{array}{l}\text { Minor lithofacies } \\
\text { type }\end{array}$ & $\begin{array}{l}\text { Architectural } \\
\text { elements }\end{array}$ & $\begin{array}{l}\text { Lithostratigraphic } \\
\text { unit }\end{array}$ & Interpretation \\
\hline FA5 & Gmm, Gmg, Sm, Fm & $\mathrm{Gp}, \mathrm{Sp}$ & $\mathrm{CH}, \mathrm{GB}, \mathrm{SB}, \mathrm{FF}$ & Upper Siwalik & $\begin{array}{l}\text { Debris flow-dominated gravelly braided } \\
\text { river }\end{array}$ \\
\hline FA4 & $\mathrm{St}, \mathrm{Sp}, \mathrm{Sm}, \mathrm{Fm}, \mathrm{Fl}$ & Gmm, Sh, Sr, P & $\begin{array}{l}\mathrm{CH}, \mathrm{SB}, \mathrm{CS}, \mathrm{LV}, \mathrm{FF} \\
\mathrm{DA}\end{array}$ & Middle Siwalik & Anastomosing river \\
\hline FA3 & $\mathrm{Sp}, \mathrm{Sr}, \mathrm{Sh}, \mathrm{Fm}$ & St, Sm, Fl, P & $\begin{array}{l}\mathrm{CH}, \mathrm{SB}, \mathrm{CS}, \mathrm{LV}, \mathrm{FF} \\
\mathrm{LA}\end{array}$ & Middle Siwalik & Sandy meandering river \\
\hline FA2 & Gmm, Sm & $\mathrm{Sr}, \mathrm{Fl}, \mathrm{Fm}$ & $\mathrm{GB}, \mathrm{SB}, \mathrm{LV}, \mathrm{FF}$ & Lower Siwalik & Flood-dominated overbank environment \\
\hline FA1 & $\mathrm{Sr}, \mathrm{Fl}, \mathrm{Fm}, \mathrm{P}$ & Sp, Sh, C & $\begin{array}{l}\mathrm{CH}, \mathrm{SB}, \mathrm{CS}, \mathrm{LV}, \mathrm{FF} \\
\mathrm{LA}\end{array}$ & Lower Siwalik & $\begin{array}{l}\text { Flood plain-dominated fine-grained } \\
\text { meandering river }\end{array}$ \\
\hline
\end{tabular}

Abbreviations: GB Gravel bars, CH Channels, SB Sandy bedforms, DA Downstream accretion, LA Lateral accretion, CS Crevasse-splay deposits, LV Levee deposits, FF Flood plain fines (Interpretation scheme after Miall 1977, 1985, 2000, 2006)

distance from the main channel caused a slowdown of the flow velocity due to which mud clasts were not transported for a long distance preventing it from further rework. The massive sandstone bed with a flat basal surface occurring in between conglomerate beds are the sheet flow deposits (Martin and Turner 1998; Miall 2006). The laminated mudstone present in between the conglomerate is deposited in a lower flow regime due to a sudden decrease in the velocity and depth of water indicating the termination of the flood. Thin to medium beds of fine-grained sandstone with facies $\mathrm{Sr}$ and $\mathrm{Fl} \mathrm{ob-}$ served at the top intraformational conglomerate represents a levee deposit (Miall 2006). The absence of channel deposits and dominance of the overbank architectural elements suggests this facies association FA2 as the deposits of the flood-dominated overbank environment.

\subsubsection{Facies association 3 (FA3)}

4.1.3.1 Description This facies association shows the domination of sandstone facies with subordinate mudstone facies. It is characterized by very thickly bedded, "salt and pepper" textured medium- to coarse-grained sandstone associated with very fine- to fine-grained sandstones and dark to greenish-grey mudstone. Mudstones are dominantly dark grey coloured, and their thickness ranges from 0.2 to $2.0 \mathrm{~m}$. These mudstones are mostly bioturbated or mottled, though facies Fl is observed in few beds.

Sandstone shows both amalgamated and nonamalgamated sandstone beds. Amalgamated sandstone beds occur intermittently with varying thickness ranging from 4 to > $20 \mathrm{~m}$ (Fig. 4C) with dominant facies Sp. Each amalgamated sandstone beds consist of 1.0 to $3.0 \mathrm{~m}$ thick individual sedimentary succession with undulating amalgamation surface. In the lower portion of amalgamated sandstone beds, individual succession shows weakly developed fining-upward succession represented by basal coarse-grained sandstone grading upward into medium- to coarse-grained sandstone at the top (Fig. 3, Sc-5) (some time amalgamation surface is unclear due to identical grain size). Subangular to angular elongated (up to $20-30 \mathrm{~cm}$ in length) mud clasts (Fig. 4D) are sporadically observed at the base of these amalgamated beds. Towards the upper portion, individual fining-upward succession ranges from coarse- to fine-grained sandstone with a distinct amalgamation surface. Occasionally thin lenses of mudstone to siltstone are preserved at the top of the individual succession (Fig.3, Sc-8). Nonamalgamated sandstone beds are fine- to coarse-grained with thickness ranging from 0.2 to $>3.0 \mathrm{~m}$. Facies $\mathrm{Sp}$ (Fig. 2F) is mainly observed in thick to very thick sandstone beds, though facies Sm (Fig. 2G) is also occasionally observed. These sandstone bears an occasional channel lags at the base composed of mud clast and coal fragments. These sandstones show a slightly erosive basal surface and lateral accretionary structures are also often observed (Fig. 4E). Thickly bedded $(50-90 \mathrm{~cm})$ fine- to medium-grained sandstone beds show sheet-like geometry and display both fining and coarseningupward succession. Facies $\mathrm{Sr}$ is dominant with planar basal surfaces and sometimes associated with mud clast. Medium- to thickly bedded $(25-50 \mathrm{~cm})$ very fine- to fine-grained sandstones show facies $\mathrm{Sh}$ or $\mathrm{Sr}$, but are mostly bioturbated. These sandstones are usually observed intercalated with mudstones. Calcareous nodules are observed on the upper portion of very fine- to finegrained sandstone and mudstone beds. Sandpipes (ca. 12 $\mathrm{cm}$ long perpendicular to bed with diameter ca. $3 \mathrm{~cm}$ ) are frequently observed in very fine-grained sandstone and mudstone. Paleocurrent analysis shows a frequent change in the flow direction with high dispersion (Fig. 1B). The FA3 facies association is preserved in the lower member of the Middle Siwalik sub-group.

4.1.3.2 Interpretation The occurrence of amalgamated sandstone beds suggests deposition by channel with a high deposition rate and high flow energy with a high erosive capacity (Zhang et al. 2017). Unclear 


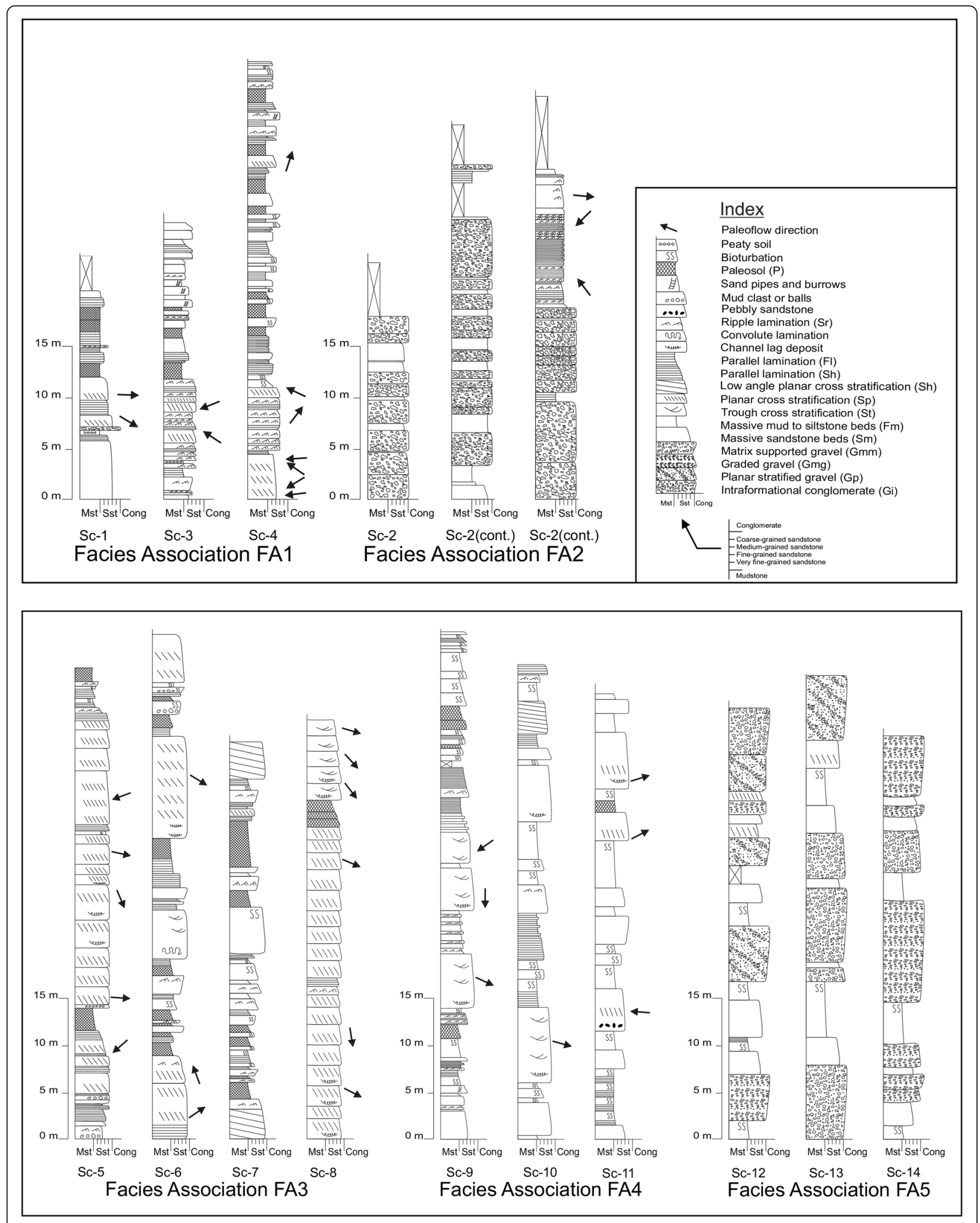

Fig. 3 Representative sedimentological log of the facies association of the Siwalik Group along the Muksar Khola section 

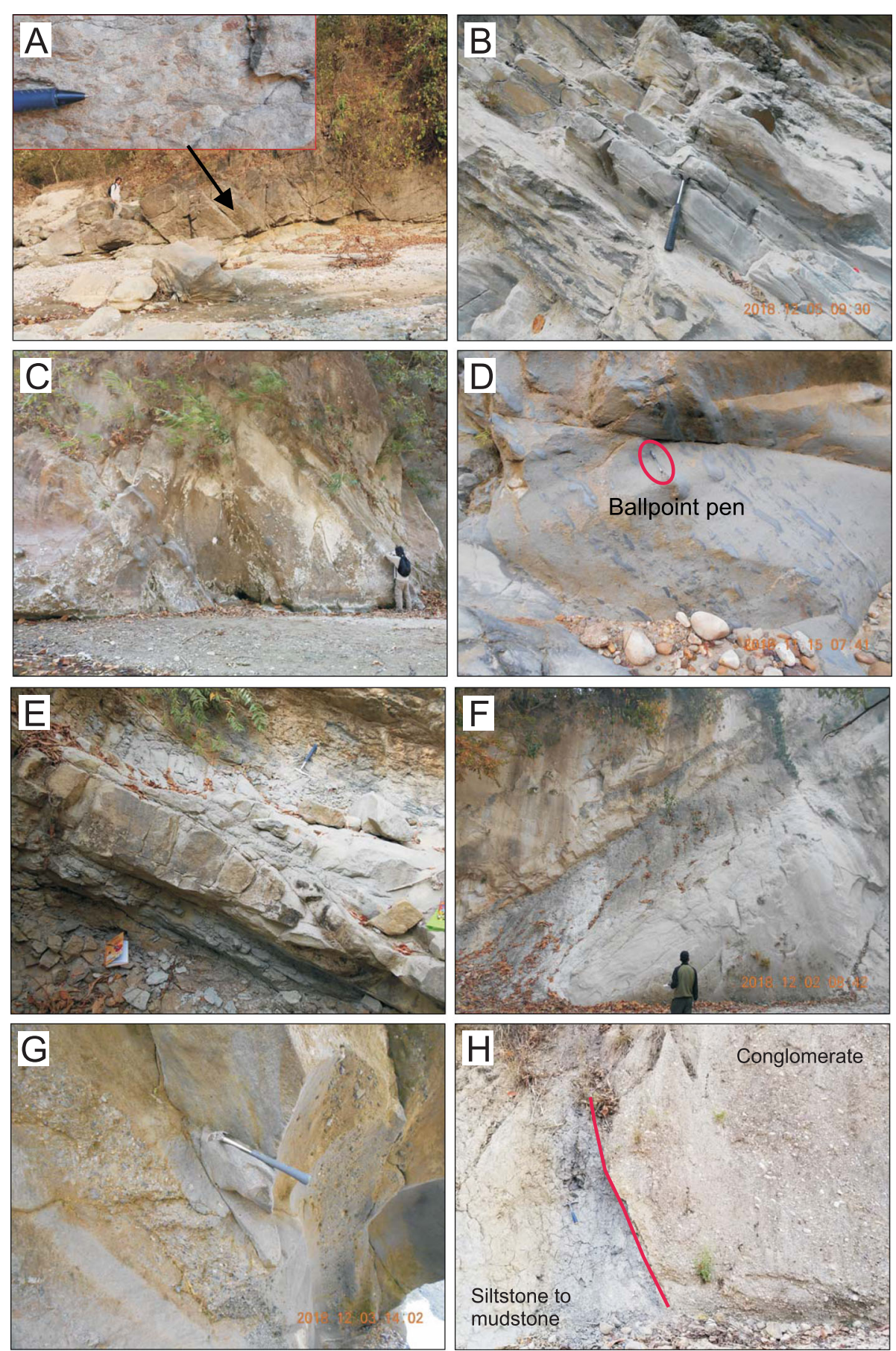

Fig. 4 Outcrop photographs of $\mathbf{A}$ intraformational conglomerate with mud clast observed in FA2, B fine-grained sandstone with parallel to ripple cross-lamination representing levee deposits of FA2, C amalgamated sandstone bed observed in FA3, D subangular to angular mud clast observed on the base of amalgamated sandstone of FA3, $\mathbf{E}$ lateral accretion observed in sandstone bed of FA3, $\mathbf{F}$ fining-upward sequence observed in a very thick bed of sandstone of FA4, G sandstone beds with channel lag deposits observed in FA4, $\mathbf{H}$ siltstone to mudstone bed and matrix-supported pebble to cobble conglomerate of FA5

amalgamation surface shows erosive features and occurs frequently within channel deposits whereas the increase in the distance from the main channel makes amalgamation surface more distinct with the occurrence of mudstone barriers (Walker 1966). Therefore, a weakly developed fining-upward succession with occasional unclear amalgamation surface in the lower section followed by the distinct amalgamation surface in the upper 
section suggests a shift of the channel. Thick to very thick sandstone beds showing fining-upward succession with channel lags and planer cross-stratification, represent deposits from the main channel (Miall 2006). Thickly bedded, bioturbated sheet-like fine- to mediumgrained sandstone with fining- or coarsening-upward succession and ripple cross-lamination (Fig. 3, Sc-6 \& 7) represents crevasse or sheet flow deposits. Very fine- to fine-grained sandstones intercalated with mudstone and showing parallel to ripple cross-laminations suggest levee deposits (Miall 2006). Thick bioturbated mudstone represents overbank deposits. Laminated mudstone represents the waning stage of river floods and swamp deposits. High dispersion of paleoflow direction, finingupward succession of sandstone with lag and lateral accretion, and thick flood plain deposits with intermittent crevasse deposits resemble the meandering river deposits (Miall 2006). On these bases, FA3 is interpreted as the deposits of the sandy meandering river system.

\subsubsection{Facies association 4 (FA4)}

4.1.4.1 Description This facies association is characterized by very thickly bedded coarse- to very coarsegrained sandstone with subordinate pebbly sandstone associated with thickly bedded fine- to medium-grained sandstone and dark grey mudstone. In this facies association, an increase in both the proportion and thickness of mudstones is observed. The overall thickness of mudstone is $>20 \mathrm{~m}$ with individual beds ranging from 0.3 to $3.0 \mathrm{~m}$. Mudstones are mostly gleyed and bioturbated, but occasionally, facies $\mathrm{Fl}$ is also observed. Variegated mudstones and carbonaceous layers are rare and observed sporadically at the upper section of this facies association.

Sandstones are less indurated compared with sandstones of FA3 and lacks a "salt and pepper" texture. The thickness of sandstone beds ranges from 1.0 to $>5.0 \mathrm{~m}$ with well-maintained fining-upward succession (Fig. 4F). Facies St (Fig. 2H) is abundant compared with facies Sp, with pebbly sandstone layers observed as a lens at the base with mostly sub-rounded quartzite clast (Fig. 4G). Very thickly bedded $(>1 \mathrm{~m})$, fine- to coarse-grained sandstones are massive with faint traces of crossstratification. In the upper portion of these facies association, downstream accretion is observed in these very thick sandstone beds. Thickly bedded medium- to coarse-grained sandstones show coarsening-upward succession with facies Sm or bioturbation. Similarly, finegrained sandstones are medium- to thickly bedded (30$70 \mathrm{~cm}$ ) with facies $\mathrm{Sr}$ or facies Sh (Fig. 2I) but are mostly bioturbated. These sandstones are associated or interlayered with mudstone beds. Paleocurrent shows the flow direction changed towards southeast from the southwest with high dispersion (Fig. 1B). This facies association FA4 is observed in the upper member of the Middle Siwalik sub-group.

4.1.4.2 Interpretation Coarse- to very coarse-grained sandstone with pebbly lags represents the channel deposits. Massive or bioturbated sandstone showing coarsening-upward succession within mudstone are crevasse or sheet flow deposits (Martin and Turner 1998) representing overbank deposits. Bioturbated fine-grained sandstone with occasional ripple cross-lamination interlayered with laminated or bioturbated mudstone suggests levee deposits. Such thick levee deposits may be the result of a comparatively stable channel. Glayed mudstone suggests the overbank deposits are influenced by a shallow or fluctuating groundwater table (Tabor et al. 2017). Such thick to very thick glayed mudstone may be the result of frequent overbank floods which accumulate fine sediments for long periods and rarely dry out completely (Sinha et al. 2005). Sporadically occurring variegated or carbonaceous layers suggest the long time exposure of flood plain. Crevasse deposits, high dispersion and repeated change in the paleoflow direction (Fig. 1B) show the sinuous nature of the channel. The well-developed fining-upward succession of sandstone beds, with a considerable proportion of flood plain deposits like crevasse or sheet flow, resembles a meandering river. Increase downstream accretion and absence of lateral accretion suggest bar deposits related to the braided river system (Almeida et al. 2016). The evidence of both the braided and meandering nature of the river and large proportion of overbank deposit bounding the sandstone beds suggests anastomosing river system (Bridge and Demicco 2008; Makaske 2001), though the anastomosing river system is hard to demonstrate in the stratigraphic log (Makaske 2001), but Miall (2006) suggested anastomosing river shows channel deposits bounded by large flood plain deposits. In the modern fluvial environment, Sinha et al. (2005) remarked anastomosing rivers are characterized by variable discharge and frequent and widespread overbank flooding. Therefore, FA4 is interpreted as deposits of an anastomosing river system.

\subsubsection{Facies association 5 (FA5)}

4.1.5.1 Description This facies association is characterized by very thick beds of poorly sorted pebble to cobble conglomerate with very coarse-grained sand to granule matrix. These conglomerate beds are associated with coarse- to very coarse-grained sandstones and dullyellowish-grey mudstones (Fig. $4 \mathrm{H}$ ) and mostly show a flat non-erosional basal surface. The clasts are mostly sub-rounded and dominated by quartzite with moderate 
purple meta-sandstone and a few sandstone, mudstone and gneiss. These conglomerates show facies Gp (Fig. 2J), facies Gmg (Fig. 2K) and facies Gmm (Fig. 2L), but dominating facies are $\mathrm{Gmg}$ and $\mathrm{Gmm}$. Facies $\mathrm{Gp}$ is rare and only observed at the lower section of this facies association. These inversely graded and stratified conglomerate beds are 0.8 to $2.0 \mathrm{~m}$ thick, amalgamated to form > $5.0 \mathrm{~m}$ thick succession. The thickness of sandstones range from 1.0 to $3.0 \mathrm{~m}$ (occasionally $>3.0 \mathrm{~m}$ ) and are almost massive. Few beds showing slight fining-upward succession bears faint planar cross-stratification. Isolated pebbles are abundant in sandstone, sometimes up to pebbly sandstone. Mudstones are thickly bedded (> $4 \mathrm{~m}$ ) and bioturbated without any pedogenic features. This facies association FA5 is observed in the Upper Siwalik sub-group.

4.1.5.2 Interpretation A poorly sorted conglomerate with inverse grading is considered to be the deposits of debris flow (Blair and MCPherson 1994; Miall 2006; Nakayama and Ulak 1999). Coarse- to very coarsegrained sandstones and pebbly sandstones with a lack of well-developed fining-upward succession represents bar deposits of the braided river system (Nakayama and Ulak 1999). Thick bioturbated mudstone represents flood plain deposits (Miall 2006). Domination of poorly sorted conglomerate with inverse grading is observed in this facies association. Thus, FA5 is interpreted as a deposit of the debris flow-dominated gravelly braided river system. The presence of thick mudstone beds within the conglomerate beds will be further discussed in the Discussion section.

\subsection{Depositional process}

Facies analysis of sedimentary succession is a useful tool to understand the depositional environment. Based on this analysis, three fluvial systems namely the meandering river, the anastomosing river and the braided river are recognized, responsible for the deposition of the Siwalik Group of rocks in the Muksar Khola section (Fig. 5). Deposition began with flood plain-dominated fine-grained meandering river system (FA1). This river system encountered a large-scale flood depositing very thick successions of intraformational conglomerate at around 10.5 Ma as flood-dominated overbank environment (FA2). The magnetostratigraphy established by Ojha et al. (2009) does not cover the Lower Siwalik subgroup section deposited before $10.0 \mathrm{Ma}$. Therefore, using their oldest sedimentation rate of $0.33 \mathrm{~mm} /$ year and the thickness of $210 \mathrm{~m}$ from the sedimentological log of Rai and Yoshida (2020), a tentative age of $10.6 \mathrm{Ma}$ is calculated. Although this age is quite speculative due to the lack of proper age data and uncertainties on the sedimentation rate, evidence from other studies (that are discussed later) suggests this age is comparable to 10.5 Ma. The dominance of the sandy beds in the meandering river system (FA3) increased after 10.0 Ma. Sporadic deposition of the amalgamated sandstone succession for a limited period is observed in this facies association. These successions are mainly noticed around $10.0 \mathrm{Ma}$, 9.4 Ma, 7.7 Ma and 6.2 Ma (Fig. 5). After 5.9 Ma, sediments were deposited by an anastomosing river system (FA4). The change from the anastomosing river system to the debris flow-dominated gravelly braided river system (FA5) occurred around 3.5 Ma.

\section{Discussion}

\subsection{Intraformational conglomerate and its relation to the monsoon intensification}

The dramatic occurrence of a large succession of the intraformational conglomerate is unique in the present study area. Such a large succession of the intraformational conglomerate has not been reported in the other Siwalik succession. Even in the previous studies of the Muksar Khola section, it was excluded by various researchers (e.g., Quade et al. 1995; Robinson et al. 2001; Chirouze et al. 2012). As mentioned above, formation of an intraformational conglomerate is related to the collapse of the distal alluvial terraces. Alluvial terraces are developed as a result of cyclic deposition of sediments and incision of the plain (Oldknow and Hooke 2017). The cause of incision in the alluvial plain of the Himalayan foreland basin can be a complex issue because various factors like climate, tectonics and eustatic fluctuations govern such incision (Mukerji 1990; Miall 2006; Tandon et al. 2006; Oldknow and Hooke 2017). In the present study area, the occurrence of such a very thick succession of intraformational conglomerate after 10.5 Ma has unique coincidence with rapid fall of the sea level around 10.5 Ma (Haq et al. 1988), rapid exhumation of the eastern Nepal Himalaya around 11.0 Ma and intensification of the Monsoon in the central Nepal Himalaya at $10.5 \mathrm{Ma}$ (Nakayama and Ulak 1999). Zaitlin et al. (1994) suggested rivers proximal to coastal areas undergo incision during the fall of sea level and aggradation as sea-level rises. If the deposition of the Lower Siwalik sub-group was proximal to the coastal area and affected by the sea-level fall and subsequent sea-level rise, then these sub-group sediments must have recoded some tidal effects (Simms et al. 2006; Guliotta et al. 2016). But, such tide-influenced deposits are not observed in the present study. Moreover, in the case of rapid sea level fall (Fig. 5), the resulting river incision is narrow and $\mathrm{V}$-shaped valleys rather than terrace morphology (Simms et al. 2006).

On the other hand, incisions due to climatic effects are mediated through variations in fluvial transport capacity. When the discharge exceeds that needed for 


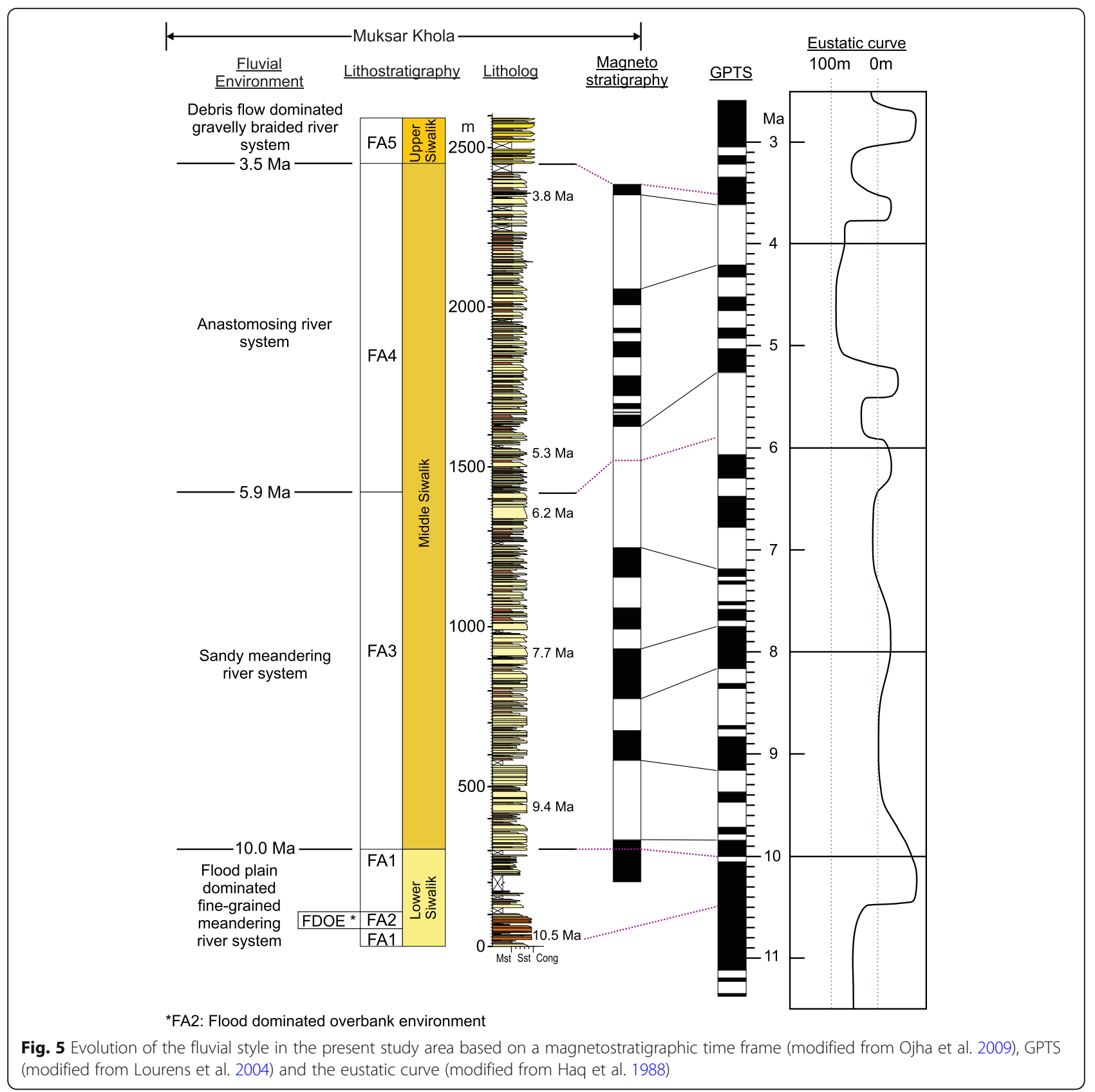

transport of the available sediment, the river promotes incision, whereas large sediment pluses can overwhelm the transport capacity of the system and cause aggradation (Bogaart et al. 2003). Generally, an increase in water discharge or high-magnitude flood is triggered only during abnormal or strengthened monsoon season (Plink-Bjorklund 2015). In the western Ganga plains, increased precipitation with monsoon intensification was reported as the controlling factors for the river incisions developed around 10.0 to $5.0 \mathrm{ka}$ (Tandon et al. 2006). The occurrence of massive coarse-grained sheet flow deposits within the intraformational conglomerate beds
(Fig. 3, Sc-1) also suggest the increase in the flow velocity since the Lower Siwalik sub-group is dominated by fine- to medium-grained sandstone. At normal flow conditions, this coarse-grained sandstone should have been trapped somewhere upstream because experiments show travel distance decreases with an increase in the particle size (Church and Hassan 1992; Parsons and Stromberg 1998). Therefore, intensification of monsoon resulting in high discharge should have favoured the river incision on the foreland basin creating alluvial terraces. During the occasional high flood event when water level drastically rises, it submerse the overbank and undercut the 
distal alluvial terrace. This subjects to the collapse of the distal alluvial terrace. The dramatic increase in sediment proportion due to this terrace collapse as well as an increase in the distance from the main channel overwhelm the transport capacity of the river resulting in aggradation of the thick intraformational conglomerate. Therefore, the occurrence of this intraformational conglomerate in the present study area at around 10.5 Ma should be related to high-magnitude floods, suggesting the monsoon intensification in the eastern Nepal Himalaya. Though there is no evidence of tideinfluenced deposits in the present study area, the effect of sea-level change cannot be denied considering the location of the present and Darjeeling-Sikkim area. The change in the sea level probably affected the regional base level of the foreland basin favouring incision.

\subsection{Controlling factors for change in river system.}

Generally, channel styles are determined by the channel slope and bankfull discharge (Leopold and Wolman 1957). The slope of the channel is controlled by the tectonics or change in the sea level (Smith and Smith 1980; Smith 1986; Burbank 1992), whereas discharge is related to tectonics and climate (Goodbred Jr and Kuehl 2000a; Clift and Giosan 2014; Clift 2017). In eastern Nepal, fast exhumation was observed after 11.0 Ma. Similarly, the eustatic curve by Haq et al. (1988) shows the rise in the sea level before 10.5 Ma (Fig. 5). Therefore, the low gradient of the foreland basin due to sea-level rise and absence of the hinterland exhumation must be the reason for the meandering river system before 10.0 Ma.

During the deposition of the lower member of the Middle Siwalik sub-group, fast exhumation was observed in the eastern Nepal Himalaya similar to its western and central counterpart (Chirouze et al. 2012). The evolution of the braided river system in western and central Nepal has a similar trend with hinterland exhumation (i.e., around 9.5 Ma in the Karnali River section and 6.5 Ma in the Surai Khola section) (Table 3). This fast exhumation of the hinterland in the eastern Nepal Himalaya could have increased the channel slope and the sediment supply, resulting in a domination of the braided river system similar to western and central Nepal. But, the tectonic history of eastern Nepal is quite different from central and western Nepal. In western and the central Nepal Himalaya, observed exhumation of the hinterland was due to the formation of the duplex structure which began at 12-10 Ma and 9.8 Ma respectively (Huyghe et al. 2001; Robinson et al. 2003; Herman et al. 2010). In the eastern Nepal Himalaya, this hinterland exhumation observed during the deposition of the lower member of the Middle Siwalik sub-group was due to the activation of the Sun Koshi Thrust (Rai et al. 2021). Therefore, the possible explanation may be asymmetric subsidence
(Burbank 1992) of the foreland basin in the eastern Nepal Himalaya. According to Burbank (1992), if thrusting is the primary cause of mountain uplift, the resultant crustal thickening causes more subsidence and deposition in the proximal parts of the foreland resulting in the restriction of the fan to the proximal area. Contrary to this, if enhanced erosion is the cause, then flexural uplift occurs across the foreland basin due to isostatic adjustment which displaces sediments to a more distal part of the basin. The imbrication of thrusts in duplex structure results in regional uplift compared with the single thrust that breaches the surface, enhancing a comparatively high rate of erosion. Robinson et al. (2001) also mention the absence of duplex structure resulted in less erosional unroofing in the eastern Nepal Himalaya compared with western and the central Nepal Himalaya. Therefore, the activation of the out-of-sequence thrust and absence of duplex structure in the eastern Nepal Himalaya could have resulted in this asymmetric subsidence and lead more sediments to be trapped in the proximal part of the basin, resulting in the starvation of sediments at the distal part where the present lower member of the Middle Siwalik sub-group was deposited.

Despite this, the episodic occurrence of a very thick succession of amalgamated sandstone beds within the sandy meandering river system (FA3) at ca. 9.4 Ma, 7.7 Ma and 6.2 Ma suggest some change in the fluvial condition. Sandstone amalgamation usually occurs in the central region of the channel suggesting a high rate of flow energy, deposition and erosive capacity and consists of two processes: erosion of inter-sand mudstone barriers and amalgamation of sandstone beds which were previously separated by the mudstone barriers (Zhang et al. 2017). As discussed above, the gradual change in the amalgamation surface from bottom to top suggests lateral shifting of the channel. But such autogenetic effects like sinuosity changes, lateral migration, accretion, and erosion is controlled by seasonal fluctuations in discharge (Slingerland and Smith 2004; Durkin et al. 2017). The subangular to angular elongated mud clasts (up to $20-30 \mathrm{~cm}$ in length) observed on the base of the amalgamated sandstone (Fig. 4D) also suggest the erosive nature of the flow giving evidence of flood as discussed above. Other than this, the occurrence of these thick succession of amalgamated sandstone successions in the present study is coeval to the timing of sea-level fall and rise (Fig. 5). The eustatic curve of Haq et al. (1988) shows a change in the sea level around $10.5 \mathrm{Ma}, 8.7 \mathrm{Ma}$, 6.6 Ma, 5.5 Ma and 3.8 Ma. Since the fluctuation of sea level should have a regional impact in the foreland basin, therefore such phenomena should be observed in the other Siwalik section. Previous studies along the Siwaliks in this time frame report domination of braided river system in the central and western Nepal Himalaya 
Table 3 Comparison of the fluvial environment of present study area with the Surai Khola section and the Karnali River section

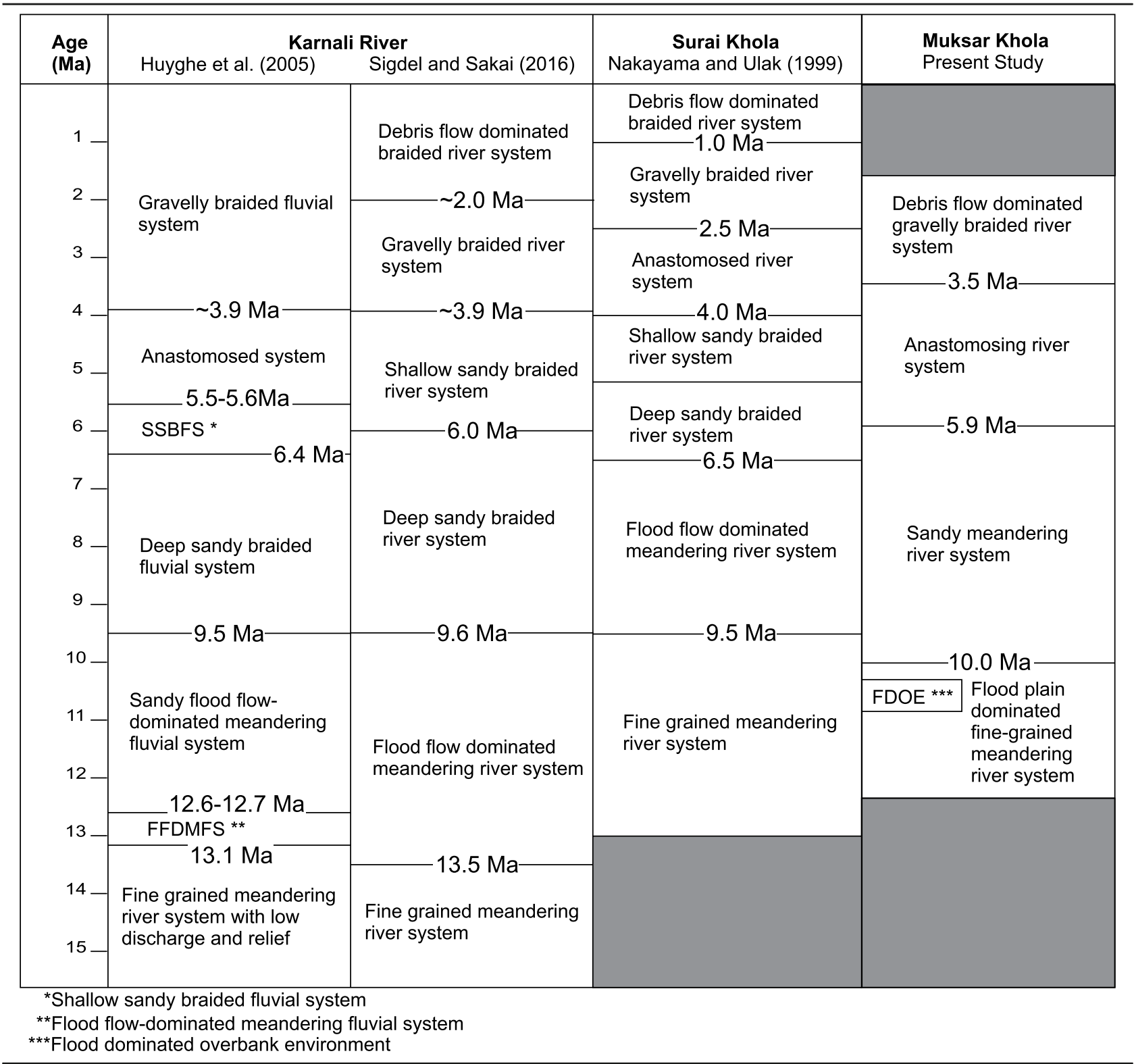

(Nakayama and Ulak 1999; Sigdel and Sakai 2016). Contrary to this, the Siwaliks in the eastern Himalaya were deposited under deltaic or open marine conditions till 5.0 Ma at Bhutan and 7.5 Ma at the Kameng River section of Arunachal Pradesh (Coutand et al. 2016; Taral et al. 2019). In the Tista valley of the Sikkim-Darjeeling area and the Kameng River sections, fluvial and deltaic environment transition is reported until the deposition of the lower part of the Upper Siwaliks (Taral et al. 2018, 2019). The present study lacks such direct evidence of deltaic or marine deposits to directly connect with sea-level change. But, the observed lithological variation in the present study which is synchronous to sealevel change suggests it should have some influence on the geometry of the foreland basin. Therefore, the occasional occurrence of very thick successions of the amalgamated sandstone should have resulted from the interplay of high discharge and sea-level rise in an asymmetrically subsidized foreland basin. The absence of evidence related to river incision as discussed above during the sea-level fall may be either due to the rate of sealevel fall (Fig. 5) or the shift of depositional area more proximal to the hinterland. If we see the eustatic curve, the rate of sea-level fall around 8.4 Ma and 6.4 Ma is not as drastic as observed around $10.5 \mathrm{Ma}$. Also, the dominating grain size of FA3 is medium- to coarsegrained sandstone suggesting depositional area somewhere upstream to the depositional area of FA1, 
suggesting a shift of the depositional area more proximal to the hinterland.

Anastomosing of rivers are controlled by climatic and geological conditions where anabranching of new channels are mainly due to the avulsion process (Nanson and Knighton 1996; Makaske 2001). The frequency of an avulsion increases with an increase in the sedimentation rate (Bridge and Leeder 1979; Bryant et al. 1995) and the base level rise (Tornqvist 1994; Makaske 2001). The base level rise may be due to the rise in the sea level (Smith and Smith 1980) and the subsidence of the foreland basin (Smith 1986). Anastomosing rivers reported in the modern fluvial environment of the Himalaya foreland basin also suggest sedimentological readjustment and tectonic subsidence of the foreland basin as the major controlling factors (Jain and Sinha 2004; Sinha et al. 2005). The rise in the sea level (Fig. 5) and the subsidence of the foreland basin after $\sim 5.5 \mathrm{Ma}$ in eastern Nepal fulfil the conditions needed for the rise in the base level of the foreland basin. Regarding the sedimentological readjustment, an increase in seasonality observed as a shift of $\mathrm{C} 3$ plants to $\mathrm{C} 4$ plants can be considered. An increase in seasonality suggests strengthening of monsoon (Quade et al. 1989, 1995) and an arid to a semiarid climatic condition, where bankfull discharge rarely exceeds more than once a year (Gibling et al. 1998) which occurs during the high magnitude floods triggered by a strengthened monsoon. During normal conditions, deposition of the sediments takes place in-channel. Consequently, the channel loses the capacity to accommodate more sediments in the next flood and becomes liable to avulsion (Makaske 2001). Various researchers also suggested the avulsion process takes place during a large flood (like Brizga and Finlayson 1990; Mack and Leeder 1998). Therefore, the rise in the base level along with the strengthening of monsoon during the deposition of the upper member of the Middle Siwalik sub-group must have favoured anastomosing river system in the present study area.

The eustatic curve after 6.0 Ma shows three events of the sea-level change (Fig. 5). These are more precise than those observed during the deposition of FA3. Considering our previous discussion, the effects of sea-level change should have brought some lithological variation, but such variation as in FA3 is absent. The probable consideration might be the shift of the depositional area more proximal to the hinterland with an increase in the distance from the sea. The overall rise in the sea level from 6.0 to 3.0 Ma resulted in the base level rise of the foreland basin on the regional scale. But the possible effects of such sea-level change around 5.3 Ma, 3.6 Ma and after 3.0 Ma was overprinted due to the hinterland tectonics and climatic controls. This shift of the depositional basin towards the hinterland concerning the depositional age suggests the foreland basin was continuously drifted north towards the hinterland.

\subsection{Significance of thick mudstone beds in Upper Siwalik sub-group}

The gravelly braided river system marked by the abrupt increase in the grain size to gravel size in the Upper Siwalik sub-group indicates a shift of the depositional basins more proximal to the hinterland. The composition of the conglomerate suggests the gravels were supplied mainly from the Lesser Himalaya Sequence. Very thick beds of sandstone (ca. $3 \mathrm{~m}$ ) and mudstone (> 4.0 $\mathrm{m})$ observed associated with a conglomerate in the present study area is quite unusual. Studies along the Siwalik section in central and western Nepal mention limited thickness or absence of such sandstone and mudstone beds in the Upper Siwalik sub-group (Nakayama and Ulak 1999; Ulak and Nakayama 2001; Sigdel and Sakai 2016). Generally, debris flows are more common in inner alluvial fan (Blair and MCPherson 1994; Miall 2006) where boulder conglomerates are reported in both paleo and modern fluvial systems (Singh et al. 1993; Nakayama and Ulak 1999; Miall 2006; Sigdel and Sakai 2016). The absence of boulder size clast (where the size of clast hardly reaches cobble size) in the present study reveals either presence of small alluvial fans or long-distance travel of debris flow. If we see the modern river system, in the foothill of the Himalaya, many small and medium rivers exist in between the large river systems. Willis (1993b) suggested small rivers exist in the fan and interfan areas that drain local area. Therefore, one possibility is the existence of a similar environment where small river fans exist and share a common or proximal basin during the deposition of FA5.

Such gravel progradation is also reported in the Nalad Khad and Jawalamukhi sections of the Himachal Pradesh (Brozovic and Burbank 2000). Brozovic and Burbank (2000) suggested three conditions for such progradation of gravels: (1) increase in the discharge and sediment flux of rivers due to climate change, (2) initiation of the MBT which led to significant erosional relief developing above it and (3) decrease in the subsidence rates of the foreland basin due to gradual hinterland erosion without major tectonism. If we consider the increase in the seasonality resulting in a strong monsoon as a factor for high discharge and sediment flux in the present study, then similar lithology should have been observed in the central Nepal Siwalik section, since the timing of monsoon intensification and vegetation change at the present study area and central Nepal are coeval. Therefore, the presence of gravel progradation only in the present study area denies the possibility of climate change as the controlling factor. In eastern Nepal, the activation of the 
MBT at the frontal margin of the Himalaya already started around 5.5 Ma (Ojha et al. 2009; Rai et al. 2021), therefore there is no possibility for the development of the erosional relief. For the third condition, if we see the hinterland tectonics of the eastern Nepal Himalaya, formation of the duplex structure at the rear of the Himalaya was observed after 4.0 Ma (Rai et al. 2021). Therefore, this duplex structure should have slow down the thrusting along the MBT. Hence, decrease in the movement of the MBT should have consequently reduced the subsidence rate. Therefore, either existence of the small alluvial fans or a decrease in the subsidence rate of the foreland basin may be the reason for the gravel progradation in the present study area.

\section{Conclusions}

From the above discussion, we came up with the following conclusions.

Five facies associations are recognized in the Neogene fluvial sediments of the Siwaliks in the Muksar Khola section of eastern Nepal. They are interpreted as flood plain-dominated fine-grained meandering river (FA1), flood-dominated overbank environment (FA2), sandy meandering river (FA3), anastomosing river (FA4) and debris flow-dominated braided river (FA5). This change in the river system occurred at around 10.5 Ma, 10.0 Ma, 5.9 Ma and 3.5 Ma respectively.

The large succession of an intraformational conglomerate in the present study gives evidence of a highmagnitude river flooding suggesting intensification of monsoon took place at $10.5 \mathrm{Ma}$ in the eastern Nepal Himalaya as a result of uplift of the eastern Nepal Himalaya.

The present study shows the hinterland tectonics and climate and sea-level change have significant effects on the Neogene foreland basin in the eastern Nepal Himalaya. The sea-level rise and absence of the hinterland exhumation during the deposition of the Lower Siwalik sub-group and asymmetric subsidence of the foreland basin due to the absence of duplex structure during the deposition of the lower member of the Middle Siwalik sub-group in the eastern Nepal Himalaya resulted in the domination of the meandering river system.

The rise in the base level due to the sea-level rise along with subsidence of foreland basin and increase in the seasonality is considered as the controlling factors for the domination of the anastomosing river during the deposition of the upper member of the Middle Siwalik sub-group.

The present study reveals continuous drifting of the foreland basin towards the hinterland. The effects of sea-level change during the deposition of the Lower Siwalik sub-group suggests the deposition area was more proximal to the sea and distal to the hinterland.
Similarly, this effect of the sea-level change was minimum during the deposition of the lower member of the Middle Siwalik sub-group and almost absent during the deposition of the upper member of the Middle Siwalik sub-group.

\section{Acknowledgements}

We thank Baburam Gyawali, Kshitiz Timsina and Manish K.C. for their assistance during fieldwork, and anonymous reviewers who significantly improved the manuscript and are gratefully acknowledged. We also acknowledge DMG (Nepal) for documentation of samples to bring to Japan. We also thank the Ministry of Education, Culture, Science and Technology of Japan for granting a Monbukagakusho (MEXT) Scholarship for PhD study to the first author.

\section{Authors' contributions}

The first author, LKR, conceptualized the research. The field study was carried out by both the author. The analysis and interpretation of data, as well as manuscript, was drafted by the first author, LKR, under the supervision of the second author, KY. Both authors read and approved the final manuscript.

\section{Funding}

This study is supported by the Japan Society for Promotion of Science (Nos. 18KK0096 and 17K05678). But, the authors declare it does not influence the results of this study.

Availability of data and materials

All data generated or analysed during this study are included in this manuscript.

\section{Declaration}

\section{Competing interests}

The authors declare that they have no competing interests.

\section{Author details}

${ }^{1}$ Department of Science and Technology, Graduate School of Medicine, Science and Technology, Shinshu University, Matsumoto, Japan. ${ }^{2}$ Institute of Science, School of Science and Technology, Shinshu University, Matsumoto, Japan.

Received: 20 January 2021 Accepted: 18 August 2021

Published online: 01 September 2021

\section{References}

Almeida RP, Freitas BT, Turra BB, Figueiredo FT, Marconato A, Janikian L (2016) Reconstructing fluvial bar surfaces from compound cross-strata and the interpretation of bar accretion direction in large river deposits. Sedimentology 63(3):609-628. https://doi.org/10.1111/sed.12230

Appel E, Rosler W (1994) Magnetic polarity stratigraphy of the Neogene Surai Khola section (Siwaliks, SW Nepal). Himal Geol 15:63-68

Armstrong HA, Allen MB (2011) Shifts in the Intertropical Convergence Zone, Himalayan exhumation, and late Cenozoic climate. Geology 39(1):11-14. https://doi.org/10.1130/G31005.1

Blair TC, MCPherson JG (1994) Alluvial fans and their natural distinction from rivers based on morphology, hydraulic processes, sedimentary processes, and facies assemblages. J Sed Res 64:450-489

Bogaart PW, Van Balen RT, Kasse C, Vandenberghe J (2003) Process-based modelling of fluvial system response to rapid climate change-l: model formulation and generic applications. Quat Sci Rev 22:2077-2095

Boos WR, Kuang Z (2010) Dominant control of the South Asian monsoon by orographic insulation versus plateau heating. Nature 463(7278):218-222. https://doi.org/10.1038/nature08707

Bridge JS, Demicco RV (2008) Earth surface processes, landforms and sediment deposits. Cambridge University Press, UK. https://doi.org/10.1017/ CBO9780511805516

Bridge JS, Leeder MR (1979) A simulation model of alluvial stratigraphy. Sedimentology 26(5):617-644. https://doi.org/10.1111/j.1365-3091.1979. tb00935.x 
Brizga SO, Finlayson BL (1990) Channel avulsion and river metamorphosis: the case of the Thomson river, Victoria, Australia. Earth Surf Proc Land 15(5):391404. https://doi.org/10.1002/esp.3290150503

Brozovic N, Burbank DW (2000) Dynamic fluvial systems and gravel progradation in the Himalayan foreland. Geol Soc Am Bull 112(3):394-412. https://doi.org/1 0.1130/0016-7606(2000)112<394:DFSAGP>2.0.CO;2

Bryant M, Falk P, Paola C (1995) Experimental study of avulsion frequency and rate of deposition. Geology 23(4):365-368. https://doi.org/10.1130/0091-7613 (1995)023<0365:ESOAFA >2.3.CO;2

Burbank DW (1992) Causes of recent Himalayan uplift deduced from deposited patterns in the Ganges basin. Nature 357(6380):680-683. https://doi.org/10.1 038/357680a0

Burchfiel BC, Chen Z, Hodges KV, Liu Y, Royden LH, Deng C, Xu J (1992) The South Tibetan Detachment System, Himalayan orogen: extension contemporaneous with and parallel to shortening in a collisional mountain belt. Geol Soc Am Spec Pap 269:1-41. https://doi.org/10.1130/SPE269-p1

Chirouze F, Bernet M, Huyghe P, Erens V, Dupont-Nivet G, Senebier F (2012) Detrital thermochronology and sediment petrology of the middle Siwaliks along the Muksar Khola section in eastern Nepal. J Asian Earth Sci 44:94-106. https://doi.org/10.1016/j.jseaes.2011.01.009

Church M, Hassan MA (1992) Size and distance of travel of unconstrained clasts on a streambed. Water Resour Res 28(1):299-303. https://doi.org/10.1029/91 WR02523

Clift PD (2017) Cenozoic sedimentary records of climate-tectonic coupling in the Western Himalaya. Prog Earth and Planet Sci 4:1-22

Clift PD, Giosan L (2014) Sediment fluxes and buffering in the post-glacial Indus Basin. Basin Res 26(3):369-386. https://doi.org/10.1111/bre.12038

Clift PD, Hodges KV, Heslop D, Hannigan R, Van Long H (2008) Calves G. Correlation of Himalayan exhumation rates and Asian monsoon intensity: Nat Geosci 1:875-880

Corvinus G (1993) The Siwalik group of sediments at Surai Khola in western Nepal and its palaeontological record. J Nepal Geol Soc 9:21-35

Coutand I, Barrier L, Govin G, Grujic D, Hoorn C, Dupont-Nivet G, Najman Y (2016) Late Miocene-Pleistocene evolution of India-Eurasia convergence partitioning between the Bhutan Himalaya and the Shillong Plateau: new evidences from foreland basin deposits along the Dungsam Chu section, eastern Bhutan. Tectonics 35(12):2963-2994. https://doi.org/10.1002/2016TC004258

Durkin PR, Boyd RL, Hubbard SM, Shultz AW, Blum MD (2017) Three-dimensional reconstruction of meander-belt evolution, Cretaceous McMurray Formation, Alberta Foreland Basin, Canada. J Sediment Res 87(10):1075-1099. https://doi. org/10.2110/jsr.2017.59

Gansser A (1964) Geology of the Himalayas. Interscience Publishers, Wiley, London

Gautam P, Appel E (1994) Magnetic-polarity stratigraphy of Siwalik Group sediments of Tinau Khola section in west central Nepal, revisited. Geophys Int 117(1):223-234. https://doi.org/10.1111/j.1365-246X.1994.tb03314.X

Gautam P, Fujiwara Y (2000) Magnetic polarity stratigraphy of Siwalik Group sediments of Karnali River section in western Nepal. Geophys J Int 142(3): 812-824. https://doi.org/10.1046/j.1365-246x.2000.00185.x

Gibling MR, Nanson GR, Maroulis JC (1998) Anastomosing river sedimentation in the Channel Country of central Australia. Sedimentology 45(3):595-619. https://doi.org/10.1046/j.1365-3091.1998.00163.x

Gohain K, Parkash B (1990) Morphology of the Kosi megafan. In: Rachocki AH, Church M (eds) Alluvial Fans: A Field Approach. John Wiley and Son Ltd, Chichester, UK, pp 151-178

Goodbred SL Jr, Kuehl SA (2000a) Enormous Ganges-Brahmaputra sediment discharge during strengthened early Holocene monsoon. Geology 28(12): 1083-1086. https://doi.org/10.1130/0091-7613(2000)28<1083:EGSDDS>2.0. $\mathrm{CO} ; 2$

Goodbred SL Jr, Kuehl SA (2000b) The significance of large sediment supply, active tectonism, and eustasy on margin sequence development: late quaternary stratigraphy and evolution of the Ganges-Brahmaputra delta. Sediment Geol 133(3-4):227-248. https://doi.org/10.1016/S0037-073 $8(00) 00041-5$

Guliotta M, Flint SS, Hodgson DM, Veiga GD (2016) Recognition criteria, characteristics and implications of the fluvial to marine transition zone in ancient deltaic deposits (Lajas Formation, Argentina). Sedimentology 63(7): 1971-2001. https://doi.org/10.1111/sed.12291

Haq BU, Hardenbol J, Vial PR (1988) Mesozoic and Cenozoic chronostratigraphy and cycles of sea-level change. In: Wilgus CK, Hastings BS, Kendall CGSC, Posamentier HW, Ross CA, Van Wagoner JC (eds) Sea-Level Changes: An
Integrated Approach, Society of Economic Paleontologists and Mineralogists, Special publication, vol, vol 42, pp 71-108. https://doi.org/10.2110/pec.88.01. 0071

Herman F, Copeland P, Avouac JP, Bollinger L, Maheo G, Le Fort P, Rai S, Foster D, Pecher A, Stuwe K, Henry P (2010) Exhumation, crustal deformation, and thermal structure of the Nepal Himalaya derived from the inversion of thermochronological and thermobarometric data and modeling of the topography. J Geophys Res 115(B6):B06407

Hisatomi K, Tanaka S (1994) Climatic and environmental changes at 9 and $7.5 \mathrm{Ma}$ in the Churia (Siwalik) Group, west-central Nepal. Himal Geol 15:161-180

Huyghe P, Galy A, Mugnier JL, France-Lanord C (2001) Propagation of the thrust system and erosion in the Lesser Himalaya: geochemical and sedimentological evidences. Geology 29(11):1007-1010. https://doi.org/1 0.1130/0091-7613(2001)029<1007:POTTSA>2.0.CO;2

Huyghe P, Mugnier JL, Gajurel AP, Delcaillau B (2005) Tectonic and climatic control of the changes in the sedimentary record of the Karnali River section (Siwaliks of western Nepal). Isl Arc 14(4):311-327. https://doi.org/10.1111/j.144 0-1738.2005.00500.x

Jain V, Sinha R (2004) Fluvial dynamics of an anabranching river system in Himalayan foreland basin, Baghmati river, north Bihar plains, India. Geomorphology 60(1-2):147-170. https://doi.org/10.1016/j.geomorph.2003.07. 008

Khan IA, Bridge JS, Kappelman J, Wilson R (1997) Evolution of Miocene fluvial environments, eastern Potwar plateau, Northern Pakistan. Sedimentology 44(2):221-251. https://doi.org/10.1111/j.1365-3091.1997.tb01522.x

Kumar R, Ghosh SK, Mazari RK, Sangode SJ (2003b) Tectonic impact on the fluvial deposits of Plio-Pleistocene Himalayan foreland basin, India. Sediment Geol 158(3-4):209-234. https://doi.org/10.1016/S0037-0738(02)00267-1

Kumar R, Ghosh SK, Sangode SJ (1999) Evolution of a Neogene fluvial system in a Himalayan foreland basin, India. Geol Soc Am Spec Pap 328:239-256

Kumar R, Ghosh SK, Sangode SJ (2003a) Mio-Pliocene sedimentation history in the northwestern part of the Himalayan Foreland Basin, India. Curr Sci 84: 1006-1013

Kumar R, Tandon SK (1985) Sedimentology of Plio-Pleistocene late orogenic deposits associated with intraplate subduction-the Upper Siwalik subgroup of a part of Panjab sub-Himalaya, India. Sediment Geol 42(1-2):105159. https://doi.org/10.1016/0037-0738(85)90076-4

Kutzbach JE, Guetter PJ, Ruddiman WF, Prell WL (1989) Sensitivity of climate to late Cenozoic uplift in southern Asia and the American west-numerical experiments. J Geophys Res 94(D15):18,393-18,407. https://doi.org/10.1029/ JD094iD15p18393

Le Fort P (1975) Himalayas: the collided range: present knowledge of the continental arc. Am J Sci 275:1-44

Leopold LB, Wolman MG (1957) River channel patterns: braided, meandering and straight. US Geol Surv Prof Pap 282B:39-85

Lourens LJ, Hilgen FJ, Laskar J, Shackleton NJ, Wilson D (2004) The Neogene period. In: Gradstein FM, Ogg JG, Smith AG (eds) A Geologic Time Scale 2004. Cambridge University Press, Cambridge, pp 409-440

Mack GH, Leeder MR (1998) Channel shifting of the Rio Grande, southern Rio Grande rift: implications for alluvial stratigraphic models. Sediment Geol 117(3-4):207-219. https://doi.org/10.1016/S0037-0738(98)00015-3

Makaske B (2001) Anastomosing rivers: a review of their classification, origin and sedimentary products. Earth-Sci Rev 53:149-196

Martin CAL, Turner BR (1998) Origins of massive-type sandstones in braided river systems. Earth-Sci Rev 44(1-2):15-38. https:/doi.org/10.1016/S0012-8252(98)00019-1

Miall AD (1977) A review of the braided river depositional environment. Earth-Sci Rev 13(1):1-62. https://doi.org/10.1016/0012-8252(77)90055-1

Miall AD (1985) Architectural-element analysis: a new method of facies analysis applied to fluvial deposits. Earth-Sci Rev 22(4):261-308. https://doi.org/10.101 6/0012-8252(85)90001-7

Miall AD (2000) Principles of sedimentary basin analysis. Springer, Verlag Berlin Heidelberg. https://doi.org/10.1007/978-3-662-03999-1

Miall AD (2006) The geology of fluvial deposits, sedimentary facies, basin analysis, and petroleum geology. Springer, Verlag Berlin Heidelberg. https://doi.org/1 0.1007/978-3-662-03237-4

Mukerji AB (1990) The Chandigarh Dun alluvial fans: an analysis of the processform relationship. In: Rachocki AH, Church M (eds) Alluvial Fans: A Field Approach. John Wiley and Son Ltd, Chichester, pp 131-149

Nakayama K, Ulak PD (1999) Evolution of fluvial style in the Siwalik Group in the foothills of the Nepal Himalaya. Sediment Geol 125(3-4):205-224. https://doi. org/10.1016/S0037-0738(99)00012-3 
Nanson GC, Knighton AD (1996) Anabranching rivers: their cause, character and classification. Earth Surf Proc Land 21(3):217-239. https://doi.org/10.1002/ (SICI)1096-9837(199603)21:3<217::AID-ESP611>3.0.CO;2-U

Ojha TP, Butler RF, Decelles PG, Quade J (2009) Magnetic polarity stratigraphy of the Neogene foreland basin deposits of Nepal. Basin Res 21(1):61-90. https:// doi.org/10.1111/j.1365-2117.2008.00374.x

Oldknow CJ, Hooke JM (2017) Alluvial terrace development and changing landscape connectivity in the Great Karoo, South Africa. Insights from the Wilgerbosch River catchment, Sneeuberg. Geomorphology 288:12-18. https://doi.org/10.1016/j.geomorph.2017.03.009

Parkash B, Sharma RP, Roy AK (1980) The Siwalik Group (molasse)—sediments shed by collision of continental plates. Sediment Geol 25(1-2):127-159. https://doi.org/10.1016/0037-0738(80)90058-5

Parsons AJ, Stromberg SGL (1998) Experiment analysis of size and distance of travel of unconstrained particles in interrill flow. Water Resour Res 34(9): 2377-2381. https://doi.org/10.1029/98WR01471

Plink-Bjorklund $\mathrm{P}$ (2015) Morphodynamics of rivers strongly affected by monsoon precipitation: review of depositional style and forcing factors. Sediment Geol 323:110-147. https://doi.org/10.1016/j.sedgeo.2015.04.004

Quade J, Cater JML, Ojha TP, Adam J, Harrison TM (1995) Late Miocene environmental change in Nepal and the northern Indian subcontinent: stable isotopic evidence from paleosols. Geol Soc Am Bull 107(12):1381-1397. https://doi.org/10.1130/0016-7606(1995)107<1381:LMECIN>2.3.CO;2

Quade J, Cerling TE, Bowman JR (1989) Development of Asian monsoon revealed by marked ecological shift during the latest Miocene in northern Pakistan. Nature 342(6246):163-166. https://doi.org/10.1038/342163a0

Rai LK, Yoshida K (2020) Lithostratigraphy of the Siwalik Group along the Muksar Khola section, Siraha-Udayapur district, eastern Nepal Himalaya. J Nepal Geol Soc 60:207-224. https://doi.org/10.3126/jngs.v60i0.31275

Rai LK, Yoshida K, Kuritani T (2021) Reconstruction of the exhumation of the eastern Nepal Himalaya based on provenance changes. Sediment Geol 420: 105920. https://doi.org/10.1016/j.sedgeo.2021.105920

Raymo ME, Ruddiman WF (1992) Tectonic forcing of late Cenozoic climate. Nature 359(6391):117-122. https://doi.org/10.1038/359117a0

Reineck HE, Singh IB (1980) Depositional sedimentary environments: with reference to terrigenous clastics. Springer, Berlin. https://doi.org/10.1007/ 978-3-642-81498-3

Robinson DM, DeCelles PG, Garzione CN, Pearson ON, Harrison TM, Catlos EJ (2003) Kinematic model for the Main Central Thrust in Nepal. Geology 31(4): 359-362. https://doi.org/10.1130/0091-7613(2003)031<0359:KMFTMC>2.0 $\mathrm{CO} ; 2$

Robinson DM, Decelles PG, Patchett PJ, Garzione CN (2001) The kinematic history of the Nepalese Himalaya interpreted from Nd isotopes. Earth Planet Sci Lett 192(4):507-521. https://doi.org/10.1016/S0012-821X(01)00451-4

Rosler W, Metzler W, Appel E (1997) Neogene magnetic polarity stratigraphy of some fluviatile Siwalik sections, Nepal. Geophys J Int 130(1):89-111. https:// doi.org/10.1111/j.1365-246X.1997.tb00990.x

Shrestha RB, Sharma SR (1996) The lower Siwalik-basement unconformity in the sub-Himalaya of eastern Nepal and its significance. J Nepal Geol Soc 13:2936

Sigdel A, Sakai T (2016) Sedimentary facies analysis os the fluvial systems in the Siwalik Group, Karnali River section, Nepal Himalaya, and their significance for understanding the paleoclimate and Himalayan tectonics. J Nepal Geol Soc 51:11-26. https://doi.org/10.3126/jngs.v51i0.24084

Simms AR, Anderson JB, Taha ZP, Rodriguez AB (2006) Overfilled versus underfilled incised valleys: examples from the Quaternary Gulf of Mexico. SEPM Spec Publ 85:117-139

Singh AB (1972) On the bedding in the natural-levee and point bar deposits of the Gomti River, Uttar Pradesh, India. Sediment Geol 7(4):309-317. https://doi. org/10.1016/0037-0738(72)90028-0

Singh H, Parkash B, Gohain K (1993) Facies analysis of the Kosi megafan deposits. Sediment Geol 85(1-4):87-113. https://doi.org/10.1016/0037-0738(93)90077-I

Sinha R, Gibling MR, Jain V, Tandon SK (2005) Sedimentology and avulsion patterns of the anabranching Baghmati River in the Himalayan foreland basin, India. In: Blum MD, Marriott SB, Leclair SF (eds) Fluvial Sedimentology VII, Special Publications of the International Association of Sedimentologist, vol, vol 35, pp 181-196. https://doi.org/10.1002/9781444304350.ch11

Slingerland R, Smith ND (2004) River avulsions and their deposits. Annu Rev Earth Planet Sci 32(1):257-285. https://doi.org/10.1146/annurev.earth.32.101802.12 0201
Smith DG (1986) Anastomosing river deposits, sedimentation rates and basin subsidence, Magdalena River, northwestern Colombia, South America. Sediment Geol 46(3-4):177-196. https://doi.org/10.1016/0037-073 8(86)90058-8

Smith DG, Smith ND (1980) Sedimentation in anastomosed river systems: examples from alluvial valleys near Banff. Alberta: J Sediment Petrol 50:157164

Tabor NJ, Myres T, Michel LA (2017) Sedimentologist's guide for recognition, description, and classification of paleosols. In: Parker W (ed) Ziegler K. Elsevier, Terrestrial Depositional Systems, pp 165-208

Tandon SK (1976) Siwalik sedimentation in a part of the Kumaun Himalaya, India. Sediment Geol 16(2):131-154. https://doi.org/10.1016/0037-0738(76)90025-7

Tandon SK, Gibling MR, Sinha S, Singh V, Ghazanfari P, Dasgupta A, Jain M, Jaim $\checkmark$ (2006) Alluvial valleys of the Ganga plains, India: timing and causes of incision. SEPM Spec Publ 85:15-35

Taral S, Chakraborty T, Huyghe P, Van Der Beek P, Vogeli N, Dupont-Nivet G (2019) Shallow marine to fluvial transition in the Siwalik succession of the Kameng River section, Arunachal Himalaya and its implication for forelan basin. J Asian Earth Sci 184:103980. https://doi.org/10.1016/j.jseaes.2019.103 980

Taral S, Sarkar S, Chakraborty T (2018) An ichnological model for a deltaic depositional system: new insights from the Neogene Siwalik foreland basin of Darjeeling- Sikkim Himalaya. Palaeogeogr Palaeoclimatol Palaeoecol 511 188-207. https://doi.org/10.1016/j.palaeo.2018.08.004

Tokuoka T, Takayasu K, Hisatomi K, Yamasaki H, Tanaka S, Konomatu M, Sah RB, Roy SM (1990) The Churia (Siwalik) Group of Tinau Khola-Binai Khola area, west-central Nepal. Mem Fac Sci Shimane Univ 24:71-88

Tornqvist TE (1994) Middle and late Holocene avulsion history of the River Rhine (Rhine-Meuse delta, Netherlands). Geology 22(8):711-714. https://doi.org/1 0.1130/0091-7613(1994)022<0711:MALHAH>2.3.CO;2

Tucker ME (2003) Sedimentary rocks in the field. England, Jhon Wiley and Sons Ltd

Ulak PD (2009) Lithostratigraphy and late Cenozoic fluvial styles of Siwalik Group along Kankai River section, East Nepal Himalaya. Bull Dept Geol Tribhuvan Univ 12:63-74

Ulak PD, Nakayama K (2001) Neogene fluvial systems in the Siwalik Group along the Tinau Khola section, west central Nepal Himalaya. J Nepal Geol Soc 25: $111-122$

Vogeli N, Najman Y, van der Beek P, Huyghe P, Wynn PM, Govin G, van der Veen I, Sachse D (2017) Lateral variations in vegetation in the Himalaya since the Miocene and implications for climate evolution. Earth Planet Sci Lett 471:1-9. https://doi.org/10.1016/j.epsl.2017.04.037

Walker RG (1966) Shale Grit and Grindslow shales: transition from turbidite to shallow water sediments in the upper Carboniferous of northern England. J Sediment Res 1:90-114

Willis BJ (1993a) Ancient river systems in the Himalayan foredeep, Chinji Village area, northern Pakistan. Sediment Geol 88(1-2):1-76. https://doi.org/10.1016/ 0037-0738(93)90151-T

Willis BJ (1993b) Evolution of Miocene fluvial systems in the Himalayan foredeep through a two kilometer-thick succession in northern Pakistan. Sediment Geol 88(1-2):77-121. https://doi.org/10.1016/0037-0738(93)90152-U

Yin A (2006) Cenozoic tectonic evolution of the Himalayan orogen as constrained by along-strike variation of structural geometry, exhumation history, and foreland sedimentation. Earth-Sci Rev 76(1-2):1-131. https://doi. org/10.1016/j.earscirev.2005.05.004

Zaitlin BA, Dalrymple RW, Boyd R (1994) The stratigraphic organization of incisedvalley systems associated with relative sea level change. In: Dalrymple RW, Boyd R, Zaitlin BA (eds) Incised-Valley Systems: Origin and Sedimentary Sequences, Society for Sedimentary Geology Special Publication, vol, vol 51, pp 45-60

Zaleha MJ (1997) Intra- and extrabasinal controls on fluvial deposition in the Miocene Indo-Gangetic foreland basin, northern Pakistan. Sedimentology 44(2):369-390. https://doi.org/10.1111/j.1365-3091.1997.tb01530.x

Zhang L, Wanf H, Li Y, Pan M (2017) Quantitaive characterization of sandstone amalgamation and its impact on reservoir connectivity. Petrol Explor Develop 44(2):226-233. https://doi.org/10.1016/\$1876-3804(17)30025-3

\section{Publisher's Note}

Springer Nature remains neutral with regard to jurisdictional claims in published maps and institutional affiliations. 